\title{
Neither Excessive Nitric Oxide Accumulation nor Acute Hyperglycemia Affects the $N$-Acetylaspartate Network in Wistar Rat Brain Cells
}

\author{
Marlena Zyśk ${ }^{1, *,+} \oplus$, Piotr Pikul ${ }^{2,+}$, Robert Kowalski ${ }^{2}{ }^{\circ}$, Krzysztof Lewandowski $^{3}$, \\ Monika Sakowicz-Burkiewicz ${ }^{1}$ (D) and Tadeusz Pawełczyk ${ }^{1}$ \\ 1 Department of Molecular Medicine, Medical University of Gdansk, 80-211 Gdansk, Poland; \\ monika.sakowicz-burkiewicz@gumed.edu.pl (M.S.-B.); tadeusz.pawelczyk@gumed.edu.pl (T.P.) \\ 2 Laboratory of Molecular and Cellular Nephrology, Mossakowski Medical Research Centre, Polish Academy \\ of Science, 80-308 Gdansk, Poland; piotr.pikul@gumed.edu.pl (P.P.); robert.kowalski@gumed.edu.pl (R.K.) \\ 3 Clinical Laboratory University Clinical Center in Gdansk, 80-211 Gdansk, Poland; \\ krzysztof.lewandowski@gumed.edu.pl \\ * Correspondence: marlena.zysk@gumed.edu.pl; Tel.: +48-58-349-2770 \\ + These authors contributed equally to this work.
}

Received: 27 September 2020; Accepted: 11 November 2020; Published: 12 November 2020

\begin{abstract}
The $N$-acetylaspartate network begins in neurons with $N$-acetylaspartate production catalyzed by aspartate $\mathrm{N}$-acetyltransferase from acetyl-CoA and aspartate. Clinical studies reported a significant depletion in $\mathrm{N}$-acetylaspartate brain level in type 1 diabetic patients. The main goal of this study was to establish the impact of either hyperglycemia or oxidative stress on the $\mathrm{N}$-acetylaspartate network. For the in vitro part of the study, embryonic rat primary neurons were treated by using a nitric oxide generator for $24 \mathrm{~h}$ followed by 6 days of post-treatment culture, while the neural stem cells were cultured in media with $25-75 \mathrm{mM}$ glucose. For the in vivo part, male adult Wistar rats were injected with streptozotocin $(65 \mathrm{mg} / \mathrm{kg}$ body weight, ip) to induce hyperglycemia (diabetes model) and euthanized 2 or 8 weeks later. Finally, the biochemical profile, NAT8L protein/Nat8l mRNA levels and enzymatic activity were analyzed. Ongoing oxidative stress processes significantly affected energy metabolism and cholinergic neurotransmission. However, the applied factors did not affect the $\mathrm{N}$-acetylaspartate network. This study shows that reduced $\mathrm{N}$-acetylaspartate level in type 1 diabetes is not related to oxidative stress and that does not trigger $N$-acetylaspartate network fragility. To reveal why $\mathrm{N}$-acetylaspartate is reduced in this pathology, other processes should be considered.
\end{abstract}

Keywords: aspartate $\mathrm{N}$-acetyltransferase; streptozotocin; SNAP; primary neurons; neural stem cells; NAA

\section{Introduction}

$\mathrm{N}$-acetylaspartate (NAA) is a brain amino acid mainly produced by neurons from acetyl-CoA and aspartate in the presence of aspartate $N$-acetyltransferase (NAT8L, Shati protein) [1-9]. Apart from NAA production, acetyl-CoA is consumed in the mitochondrial tricarboxylic acid cycle, while aspartate has to be shared with the malate-aspartate shuttle (Figure 1) [1-9]. $N$-acetylaspartate is used by neurons to conduct crosstalk with glial cells, thus NAA disturbances reflect dysregulations of brain homeostasis [1-15]. A couple of diseases listed as involving NAA disturbances share a few molecular pathomechanisms (such as the upregulation of oxidative stress), although they have a wide clinical background, and no connections with NAT8L have been discussed [1-9]. 


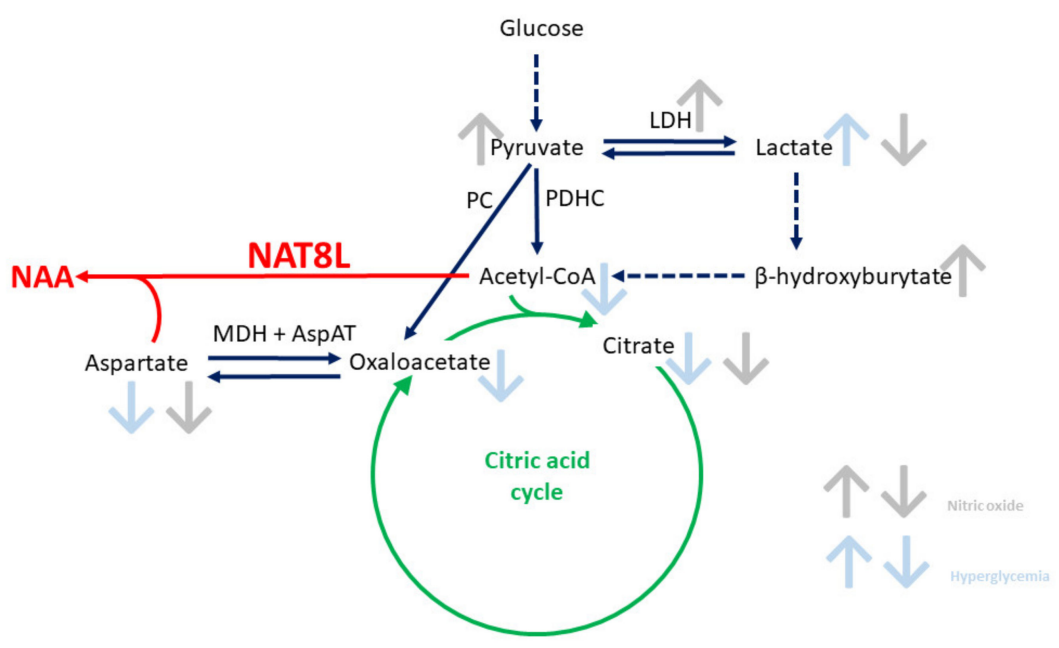

Figure 1. Graphic presentation of the background of this study background: the impact of neurotoxic factors on the $\mathrm{N}$-acetylaspartate network related to neuronal energy pathways. Abbreviations: AspAT: aspartate transferase; $\mathrm{LDH}$ : lactate dehydrogenase; $\mathrm{MDH}$ : malate dehydrogenase; NAA: $\mathrm{N}$-acetylaspartate; NAT8L: aspartate $\mathrm{N}$-acetyltransferase (or Shati protein); PC: pyruvate carboxylase; PDHC: pyruvate dehydrogenase complex.

Type 1 diabetes mellitus (T1D) is an insulin-dependent chronic metabolic disease that most often develops during childhood and is caused by autoimmune reaction leading to impaired insulin production [16-18]. Lack of the endogenous insulin resulted in an abnormal elevation of blood glucose level [16-18]. Uncontrolled hyperglycemia might evoke a metabolic crisis, such as lactic acidosis, ketoacidosis, and finally oxidative stress [16]. Moreover, several clinical studies reported significantly lower brain NAA level measured in type 1 diabetic patients [16-18]. Since the NAA network interweaves energy pathways that are susceptible to oxidative stress, we assumed that the NAA network will be vulnerable to these conditions as well. Therefore, our overall goal was to identify biochemical variables that might decrease the NAA brain level in the progression of type 1 diabetes. To separate the impact of oxidative stress and hyperglycemia effects on NAA network, the investigated in vitro models were exposed to either a high concentration of nitric oxide from a generator (model of oxidative stress) or to acute hyperglycemia. Streptozotocin-injected Wistar rats were sacrificed as in vivo model of type 1 diabetes. As results, our studies revealed that oxidative stress is not an up- or downregulating factor for the NAA network. We also noted that brain cells can handle shortages of $\mathrm{N}$-acetylaspartate substrates. Therefore, we hypothesize that to regulate the NAA network, NAT8L enzymatic activity or gene expression have to be regulated rather than substrate shortages.

\section{Results and Discussion}

\subsection{Primary Cell Cultures}

In these studies, we used two primary brain cell lines isolated from E18 embryos (Wistar rats). Primary neuronal culture was used to analyze the biochemical profile of neurons cultured without glial cells. Meanwhile, neural stem cells (NSC) provided the authors with data about the $N$-acetylaspartate network resulting from interactions between neurons and glial cells (cell types recognized in NSC: $70-80 \%$ astrocytes, $20-25 \%$ neurons, and up to $5 \%$ oligodendrocytes) (Figure 2a) [19]. 


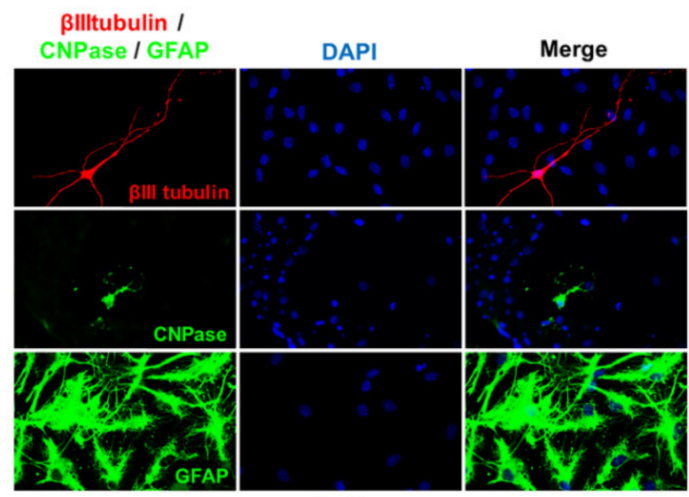

(a)

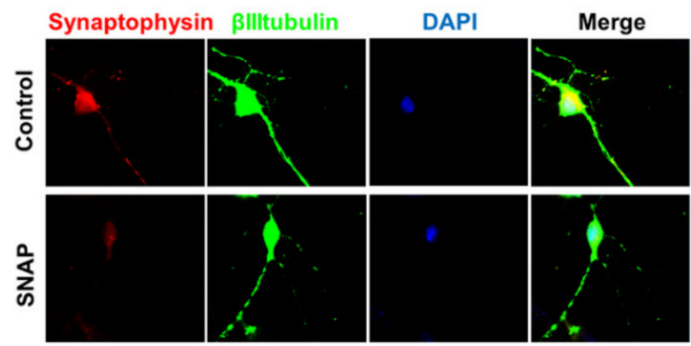

(c)

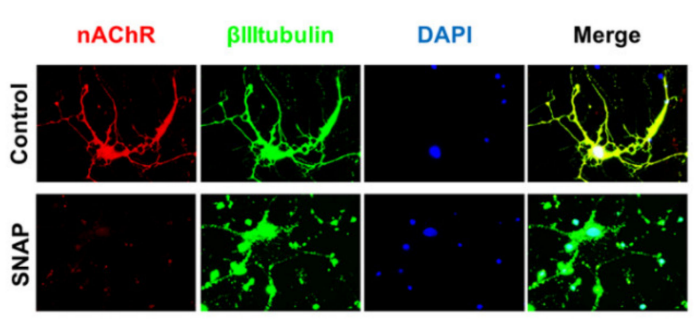

(b)

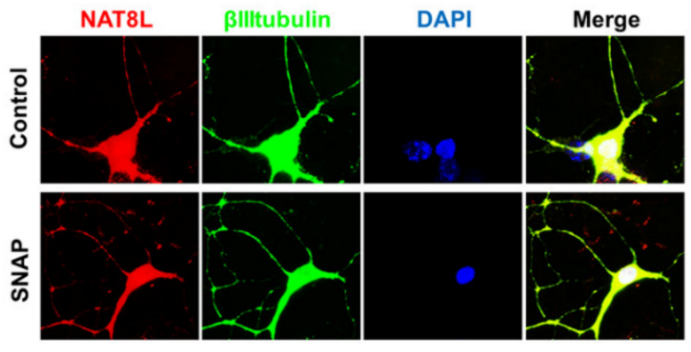

(d)

Figure 2. The immunostaining made for the purposes of this project: (a) cell types recognized in the neural stem cells model stained by the antibody against $\beta$-III-tubulin (neuronal marker), CNPase ( $2^{\prime}, 3^{\prime}$-Cyclic-nucleotide $3^{\prime}$-phosphodiesterase, oligodendrocytic marker) and glial fibrillary acidic protein

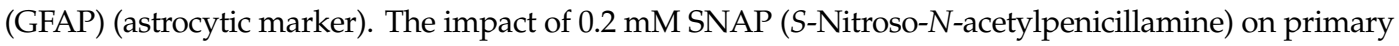
neurons stained by the antibody against $\beta$-III-tubulin and: (b) nicotinic acetylcholine receptor (nAChR); (c) synaptophysin; (d) NAT8L. The images are representative for four independent sets of experiments.

Primary neurons should express a neuronal phenotype in terms of their characteristic morphology as well as higher glucose turnover when compared to glial cells [20-22]. To reach this phenotype, primary cells were allowed to mature for two weeks in neurobasal media supplemented with nerve growth factor (Materials and methods). Next, we analyzed the reaction carried out by the pyruvate dehydrogenase complex (PDHC), which introduces pyruvate and coenzyme A (CoA) to produce acetyl-CoA (Figure 1) [23]. Consequently, acetyl-CoA enters the tricarboxylic acid cycle and initiates the oxidative phosphorylation metabolism pathway (Figure 1) [23,24]. Alternatively, pyruvate can be consumed as a source either for oxaloacetate or lactate (Figure 1). Our data showed that primary neurons had significantly higher PDHC activity than neural stem cells $(17.7$ and $7.0 \mathrm{nmol} / \mathrm{min} / \mathrm{mg}$ protein, respectively) ( $p<0.05$ ) (Table 1$)$. Furthermore, primary neurons (PR), compared to neural stem cells (NSC), have a higher intracellular pyruvate concentration together with an equal acetyl-CoA level (Table 2 and Figure 3a). This indicates that our culture approach provides the PR cells with a high glucose turnover, resulting in a high pyruvate level (Table 2). Meanwhile, an unchanged acetyl-CoA level in primary neurons is linked with high acetyl-CoA consumption in the tricarboxylic acid cycle. Such consumption is reflected here by significantly higher citrate and oxaloacetate levels as well as significantly higher aconitase activity $(p<0.01, p<0.05$, and $p<0.05$, respectively) (Tables 1 and 2 and Figure 3a). With this primary neuronal culture approach, the primary neurons develop a strong neuronal network with a typical "neuron-like" morphology (Figure 4a). 
Table 1. Enzymatic activities measured in Wistar rat brains.

\begin{tabular}{|c|c|c|c|c|}
\hline Parameter & Added & Primary Neurons & Neural Stem Cells & $\begin{array}{l}\text { Wistar Rat's } \\
\text { Brain Tissue }\end{array}$ \\
\hline \multirow{4}{*}{$\begin{array}{l}\text { Pyruvate dehydrogenase complex } \\
\text { nmol/min } / \mathrm{mg} \text { protein }\end{array}$} & Control/Sham & $17.7 \pm 4.9$ & $7.0 \pm 3.0$ & $23.8 \pm 9.9$ \\
\hline & 0.2 mM SNAP & $22.8 \pm 6.8$ & & \\
\hline & $50 \mathrm{mM}$ glucose & & $6.2 \pm 2.0$ & \\
\hline & $\mathrm{mDM}$ & & & $17.4 \pm 4.9$ \\
\hline \multirow{2}{*}{$\begin{array}{l}\text { Lactate dehydrogenase } \\
\mu \mathrm{mol} / \mathrm{min} / \mathrm{mg} \text { protein }\end{array}$} & Control/Sham & & $0.4 \pm 0.1$ & $1.3 \pm 0.4$ \\
\hline & $\begin{array}{c}50 \mathrm{mM} \text { glucose } \\
\text { mDM }\end{array}$ & & $0.5 \pm 0.6^{* *}$ & $1.0 \pm 0.6$ \\
\hline \multirow{2}{*}{$\begin{array}{l}\text { Aspartate aminotransferase } \\
\mathrm{nmol} / \mathrm{min} / \mathrm{mg} \text { protein }\end{array}$} & Control/Sham & & $0.2 \pm 0.05$ & $0.4 \pm 0.2$ \\
\hline & $\begin{array}{c}50 \mathrm{mM} \text { glucose } \\
\text { mDM }\end{array}$ & & $0.2 \pm 0.05$ & $0.5 \pm 0.2$ \\
\hline Hexokinase & Control/Sham & & & $26.0 \pm 7.0$ \\
\hline$\mu \mathrm{mol} / \mathrm{min} / \mathrm{mg}$ protein & $\mathrm{mDM}$ & & & $59.0 \pm 33.0$ \\
\hline \multirow{3}{*}{$\begin{array}{c}\text { Citrate synthase } \\
\mu \mathrm{mol} / \mathrm{min} / \mathrm{mg} \text { protein }\end{array}$} & $\begin{array}{l}\text { Control/Sham } \\
50 \mathrm{mM} \text { glucose }\end{array}$ & & $\begin{array}{c}34.3 \pm 4.0 \\
41.8 \pm 5.3^{* *}\end{array}$ & $44.4 \pm 19.6$ \\
\hline & $\mathrm{mDM}$ & & & $35.4 \pm 15.4$ \\
\hline & Control/Sham & $36.4 \pm 9.3$ & $23.0 \pm 7.2$ & $31.5 \pm 11.1$ \\
\hline Aconitase & 0.2 mM SNAP & $48.4 \pm 12.7^{*}$ & & \\
\hline \multirow[t]{2}{*}{$\mu \mathrm{mol} / \mathrm{min} / \mathrm{mg}$ protein } & $\begin{array}{l}50 \mathrm{mM} \text { glucose } \\
\text { mDM }\end{array}$ & & $30.0 \pm 6.5$ & $26.8 \pm 16.9$ \\
\hline & Control/Sham & $68.3 \pm 22.3$ & $56.7 \pm 11.1$ & $14.7 \pm 7.1$ \\
\hline Isocitrate dehydrogenase & 0.2 mM SNAP & $80.2 \pm 34.7$ & & \\
\hline$\mu \mathrm{mol} / \mathrm{min} / \mathrm{mg}$ protein & $\begin{array}{l}50 \mathrm{mM} \text { glucose } \\
\text { mDM }\end{array}$ & & $61.9 \pm 8.4$ & $9.6 \pm 5.8$ \\
\hline
\end{tabular}

Data are means \pm SD from 12-16 (for in vivo studies) or 5-14 (for in vitro studies) observations per group. Significantly different from the control: ${ }^{*}(p$-value $<0.05)$, ${ }^{* *}(p$-value $<0.01)$. Abbreviations: SNAP: $S$-Nitroso- $N$-acetylpenicillamine

Table 2. Metabolite levels measured in Wistar rat brains.

\begin{tabular}{|c|c|c|c|c|}
\hline Parameter & Added & Primary Neurons & Neural Stem Cells & $\begin{array}{l}\text { Wistar Rat's } \\
\text { Brain Tissue }\end{array}$ \\
\hline & Control/Sham & $50.7 \pm 27.0$ & $24.9 \pm 8.5$ & $13.2 \pm 7.4$ \\
\hline Pyruvate & 0.2 mM SNAP & $25.3 \pm 15.5^{* *}$ & & \\
\hline \multirow[t]{3}{*}{$\mathrm{nmol} / \mathrm{mg}$ protein } & $50 \mathrm{mM}$ glucose & & $75.2 \pm 23.7^{* *}$ & \\
\hline & $\mathrm{mDM}$ & & & $10.3 \pm 5.5$ \\
\hline & Control/Sham & $15.3 \pm 4.3$ & $10.7 \pm 5.5$ & $25.0 \pm 11.3$ \\
\hline Lactate & 0.2 mM SNAP & $49.5 \pm 15.2 * * *$ & & \\
\hline \multirow[t]{2}{*}{$\mathrm{nmol} / \mathrm{mg}$ protein } & $50 \mathrm{mM}$ glucose & & $5.7 \pm 5.1$ & \\
\hline & $\mathrm{mDM}$ & & & $35.3 \pm 12.3^{* *}$ \\
\hline \multirow{3}{*}{$\begin{array}{c}\text { Citrate } \\
\mathrm{nmol} / \mathrm{mg} \text { protein }\end{array}$} & Control/Sham & $45.8 \pm 13$ & $26.4 \pm 9.3$ & \\
\hline & 0.2 mM SNAP & $16.9 \pm 11.2^{* *}$ & & \\
\hline & $50 \mathrm{mM}$ glucose & & $10.4 \pm 4.7^{* * *}$ & 05 \\
\hline \multirow{3}{*}{$\begin{array}{c}\text { Oxaloacetate } \\
\text { nmol/mg protein }\end{array}$} & 0.2 mM SNAP & $\begin{array}{l}5.1 \pm 0.0 \\
3.1 \pm 2.5 *\end{array}$ & $2.3 \pm 0.9$ & $0.0 \pm 0.4$ \\
\hline & $50 \mathrm{mM}$ glucose & & $2.8 \pm 1.5$ & \\
\hline & $\mathrm{mDM}$ & & & $0.4 \pm 0.1$ \\
\hline
\end{tabular}

Data are means \pm SD from 14-16 (for in vivo studies) or 5-12 (for in vitro studies) observations per group. Significantly different from control: ${ }^{*}(p$-value $<0.05),{ }^{* *}(p$-value $<0.01),{ }^{* * *}(p$-value $<0.001)$. 


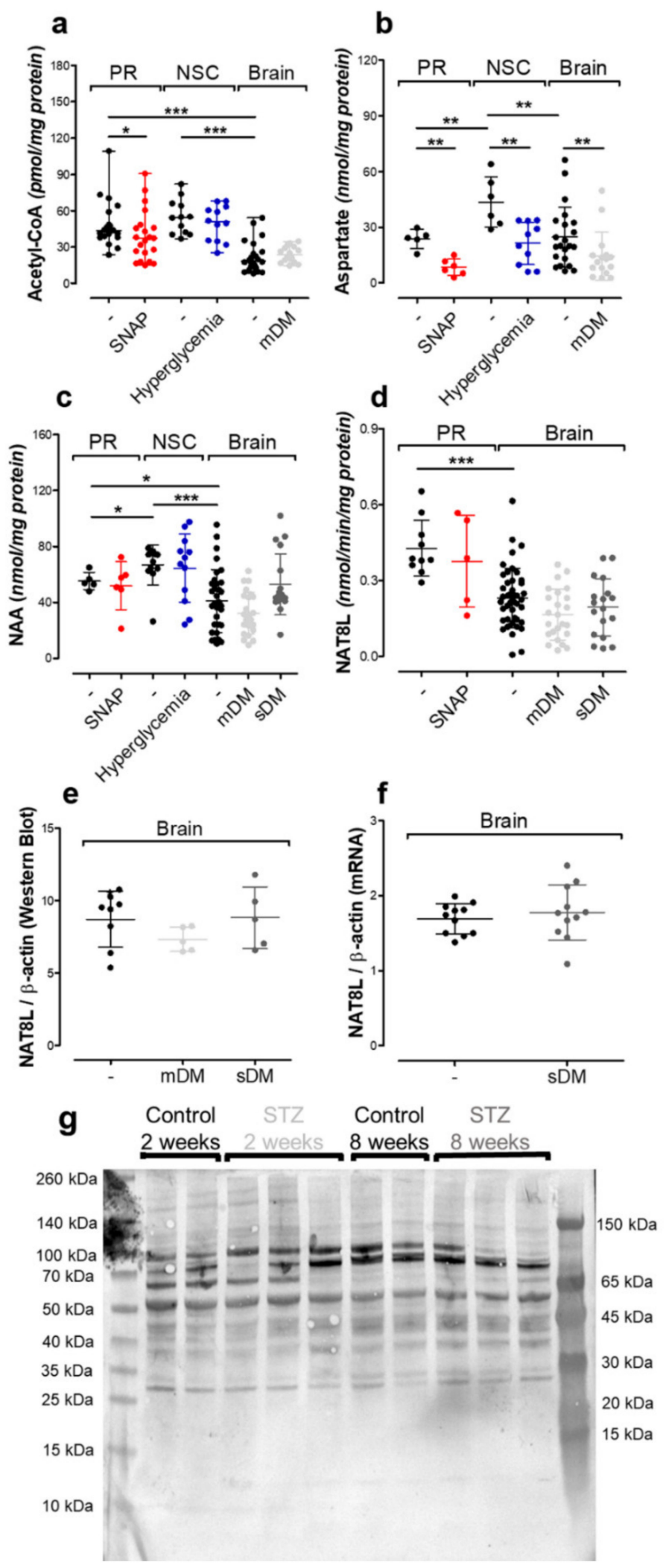

Figure 3. The impact of toxic factors on the NAA network measured in primary neurons (PR), neural stem cells (NSC) and brain tissue (Brain): (a) acetyl-CoA level; (b) aspartate level; (c) N-acetylaspartate level; (d) aspartate $N$-acetyltransferase (NAT8L) activity; (e) NAT8L protein level (Western blot); (f) Nat8l mRNA level (real-time RT-qPCR); (g) representative WB (Western Blot) membrane image for NAT8L protein. Data are means \pm SD from 5-22 observations per group. Significantly different from the control: ${ }^{*}(p$-value $<0.05),{ }^{* *}(p$-value $<0.01),{ }^{* *}(p$-value $<0.001)$. 

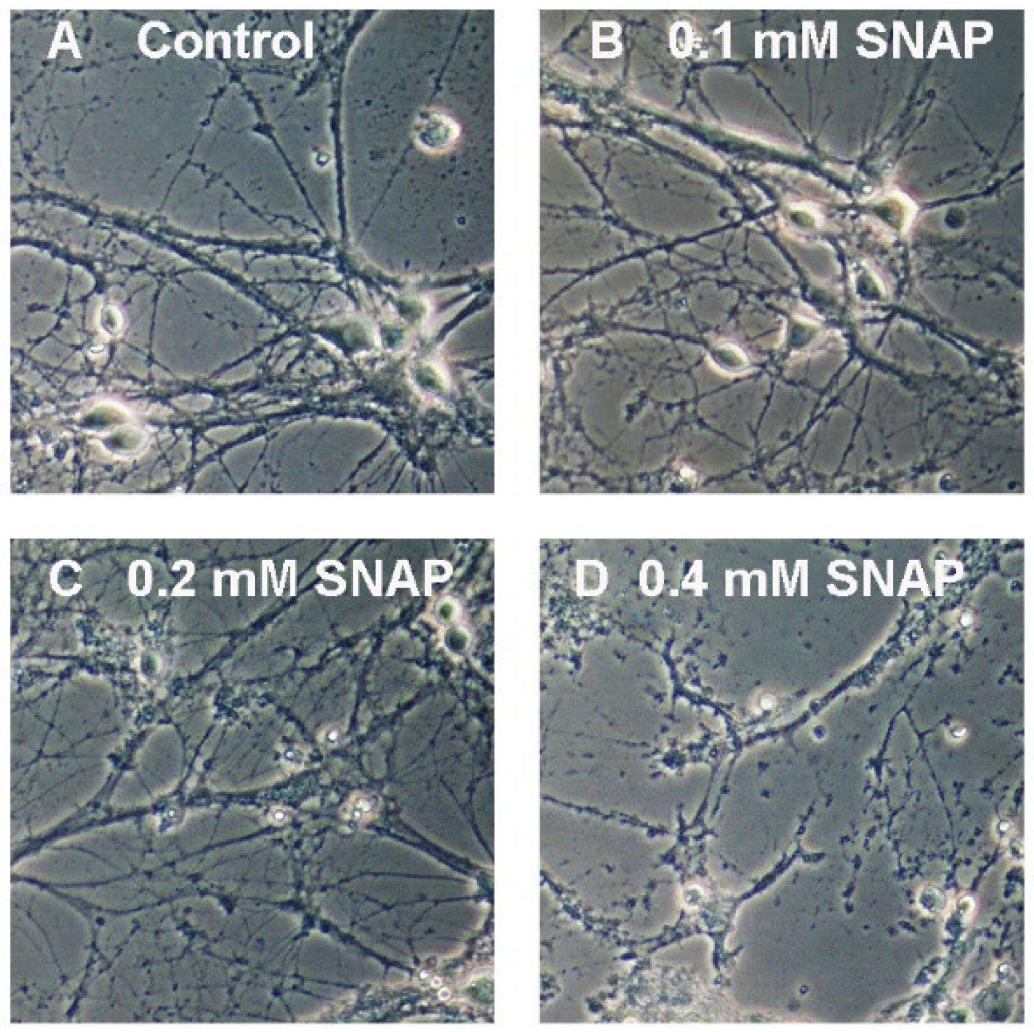

Figure 4. The impact of neurotoxic factors on primary neurons morphology or the $N$-acetylaspartate network related to neuronal energy pathways. The impact of SNAP: (a) control; (b) 0.1 mM SNAP; (c) 0.2 mM SNAP (in further experiments, used as basic SNAP concentration); (d) 0.4 mM SNAP.

\subsection{Nitric Oxide Affects Primary Neurons Morphology and Energy State}

Our previous study showed that the $24 \mathrm{~h}$ treatment with neurotoxic $\mathrm{Zn}^{2+}$ concentrations resulted in a severe reduction of the $N$-acetylaspartate (NAA) level in SN56 neuroblastoma cells (the cellular model of cholinergic neurons) [9,25]. Further studies confirmed the significant reduction of acetyl-CoA (NAA substrate) and the suppression of NAT8L (an enzyme producing NAA) activity as well [9]. In our other studies, we noted that $\mathrm{Zn}^{2+}$-dependent NAT8L inhibition may be caused either by direct unspecific enzyme inhibition or by the promotion of oxidative stress affecting NAT8L activity. Therefore, considering these studies as well as the experimental studies showing that hyperglycemia may enhance NO production [26-29], we decided to expose primary neurons to the excess nitric oxide concentrations. SNAP (S-nitroso- $N$-acetylpenicillamine) is a commonly known nitric oxide (NO) generator releasing nitric oxide to culture media during the first hours of treatment [30]. In our studies, we used this generator to check whether SNAP-triggered neurodegeneration would affect $N$-acetylaspartate network homeostasis. Toxic SNAP concentration was established empirically starting from the $24 \mathrm{~h}$ treatment followed by 6 days of post-treatment culture (Materials and Methods). These 6 additional days of culture were added to analyze the reaction of stressed primary neurons. In terms of their morphology, 0.1 mM SNAP did not affect neuronal morphology (neither cell bodies nor neuronal networks were affected) (Figure $4 \mathrm{~b})$. Two times higher SNAP concentration $(0.2 \mathrm{mM})$ dramatically affected the neuronal cell bodies, although to reach a visible disconnection of the neuronal network, we had to use SNAP in a concentration of at least $0.4 \mathrm{mM}$ (Figure $4 \mathrm{c}, \mathrm{d}$ ). Using immunostaining against either the nicotinic acetylcholine receptor (nAChR) or synaptophysin, we learnt that $0.2 \mathrm{mM} \mathrm{SNAP}$ affected the cholinergic neurotransmission as well (Figure $2 b, c)$. To connect nitric oxide toxicity with energy metabolism and the NAA network, the cell viability tests were measured. Lactate dehydrogenase (LDH) in media activity is well known as a membrane integrity test, while the methylthiazolyldiphenyl-tetrazolium bromide (MTT) test is an indicator for mitochondrial health. Each of the tested SNAP concentrations 
caused severe energy disruption, although only 0.8 mM SNAP caused a significant leakage of LDH enzyme to the culture media $(p<0.01)$ (Figure 5a). Furthermore, comparing 3 days and 6 days of post-treatment experimental time points, we observed that the energy shortages measured by the MTT test might have been partially reversible (Figure 5b). All these findings are consistent with the literature [30]. Next, we analyzed nitric oxide (NO) levels in both media (extracellular) and cells (intracellular). Since NO has a very short half-life, we assayed secondary NO metabolites, assuming them to be indirect indicators of NO-generation efficiency and cellular influx rate. Thus, we used a Griess assay to test nitrite levels in the media, while DAF-2 (4,5-diaminofluorescein diacetate) dyes were used to test the oxidation product of nitric oxide. To make the results less complex to analyze, they are reported as NO levels (Figure $5 \mathrm{c}, \mathrm{d}$ ). In the culture media, $0.2 \mathrm{mM}$ SNAP reached the highest efficiency in NO production during the first $3 \mathrm{~h}$ of treatment, while cellular accumulation reached a plateau point after $24 \mathrm{~h}$ of treatment (Figure $5 \mathrm{c}, \mathrm{d}$ ). Compared to 0.2 mM SNAP, $0.8 \mathrm{mM}$ SNAP generated two times more nitric oxide molecules in the media, although intracellular nitric oxide level was higher only by about $25 \%$. However, since $0.8 \mathrm{mM}$ SNAP disintegrates neuronal membranes, such concentration might artificially upregulate the intracellular NO level (Figure 4d). Then, $24 \mathrm{~h}$ exposure to 0.4 and $0.8 \mathrm{mM}$ SNAP with an additional 6 days of culture resulted in considerable changes in the primary neuronal cells' morphology, occurring together with severe LDH leakage as well as a more than $50 \%$ reduction in MTT level (Figures 4a-d and 5a-d). Here, we assumed that these concentrations are lethal for the primary neuronal culture; therefore, in further studies, we used 0.2 mM SNAP.

The accumulation of free radicals is the most common effect of excessive nitric oxide production, which we noted as a significant upregulation of thiobarbituric acid reactive substances (TBARS) level (a marker of cytoplasmic oxidative stress) $(p<0.01)$, although mitochondrial stress markers remained unchanged (aconitase, isocitrate dehydrogenase) (Table 1 and Figure 6e) [30]. The nitric oxide-triggered cytoplasmic disruptions came with severe outcomes regarding the levels of metabolites (Table 2 and Figures 1 and $3 a, b)$. Recently, NO has been reported to inhibit the pyruvate dehydrogenase activity [31,32]. We hypothesize that excess nitric oxide inhibits pyruvate dehydrogenase complex activity, which slows down the tricarboxylic acid cycle and malate-aspartate shuttle (diminished levels of citrate, oxaloacetate, acetyl-CoA, and aspartate) (Tables 1 and 2 and Figures 1 and 3a). However, since our method measure enzyme activity in adaptive conditions, we did not note any changes in pyruvate dehydrogenase activity (Table 1). In order to keep stable the ATP flux, energy metabolism has been partially rerouted to LDH-dependent pathway vigorously consumed pyruvate resulting with the significant elevation of the lactate level $(p<0.001)$ (Tables 1 and 2) [22,23]. Described impairment reflects metabolic disturbances under diabetic ketoacidosis; therefore, these conditions have been used to analyze the NAA network further in this study.

\subsection{Hyperglycemia Affects Neural Stem Cells Mitochondrial Homeostasis}

In research on diabetes, discussion has increasingly become focused on the neuropathology created by unstable glycemia in blood cells involved in the vascular system surrounding the brain cells [33]. Under physiological circumstances, glucose is transported from the bloodstream to brain cells via blood-brain barrier glucose-specific transporters, predominantly GLUT1. Uncontrolled hyperglycemia could dramatically increase the neuronal glucose level, which leads to neuronal damage, known as glucose neurotoxicity [33]. Since glucose-derived energy metabolism and the $N$-acetylaspartate network (NAA network) are closely connected with each other, we consider hyperglycemia as one of the potential risk factors for NAA network stability (Figure 1). To conduct energy metabolism, neurons are fed by astrocytes through neuronal-astrocyte coupling with glucose and lactate [34]. Therefore, the impact of hyperglycemia on the NAA network has been studied using neural stem cells (NSC) instead of primary neurons. Here, we used a widely known in vitro model of hyperglycemia with a daily change of media [35]. The final glucose concentration in the culture media ranged between 25 and $75 \mathrm{mM}$ (Materials and methods). 

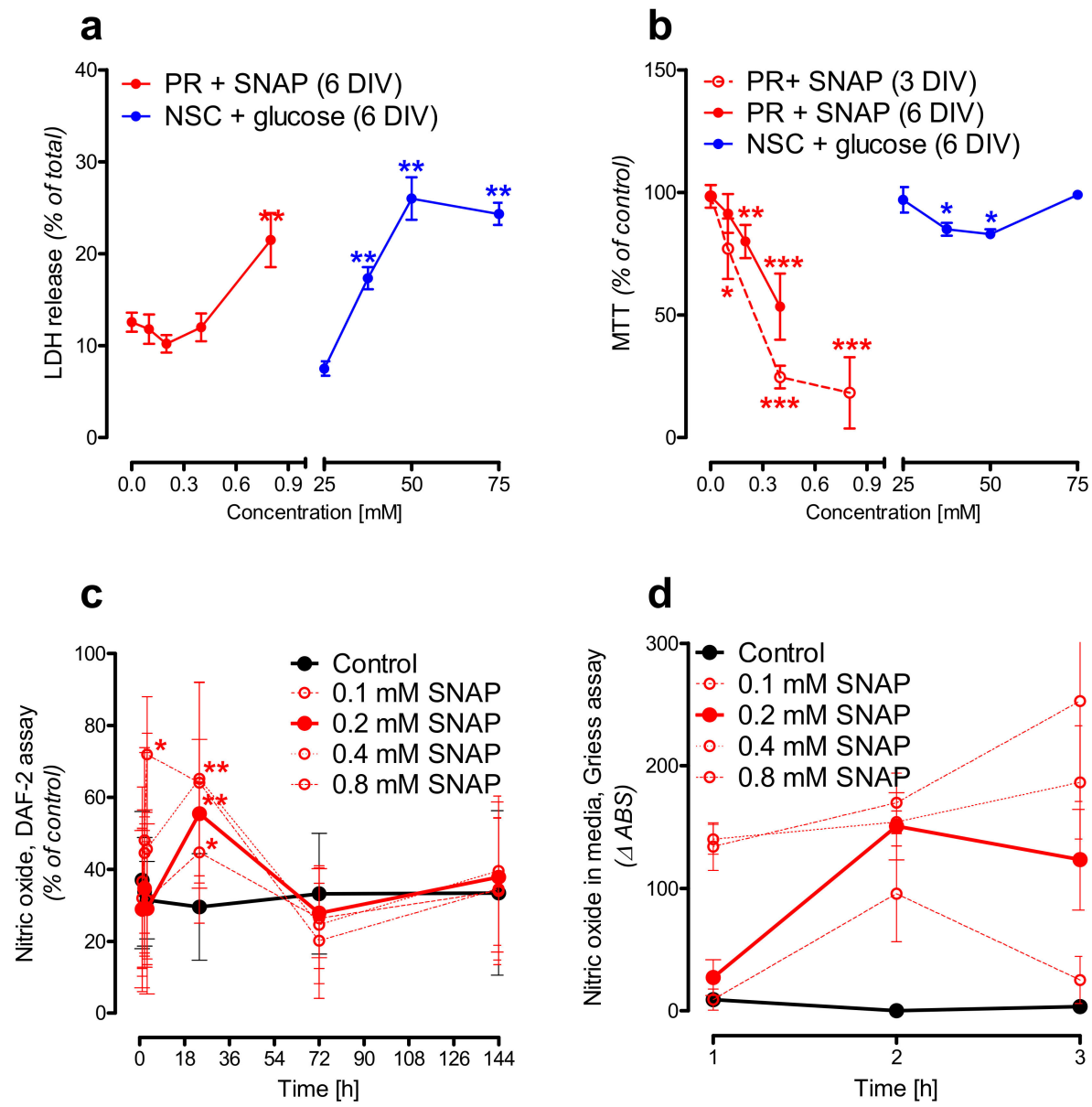

Figure 5. The impact of toxic factors on primary cells. $(\mathbf{a}, \mathbf{b})$ viability tests in both primary cell lines; (c,d) nitric oxide accumulation in primary neurons (PR). (a) LDH in media test; (b) methylthiazolyldiphenyl-tetrazolium bromide (MTT) test; (c) intracellular accumulation of nitric oxide (DAF-2 fluorescence assay); (d) in media accumulation of nitric oxide (Griess spectrophotometric assay). Data are means \pm SD from 3 to 20 observations per group. Significantly different from the control: ${ }^{*}(p$-value $<0.05),{ }^{* *}(p$-value $<0.01),{ }^{* * *}(p$-value $<0.001)$.

The LDH test showed glucose-dependent membrane disruption (Figure 5a), although NSC morphology did not support these findings (data not shown). Such an unusual phenomenon arose from the upregulation of LDH activity in NSC cells cultured in hyperglycemic conditions (Table 1). In the control conditions (NSC cells cultured in media with $25 \mathrm{mM}$ glucose), the LDH cellular activity was $0.4 \mu \mathrm{mol} / \mathrm{min} / \mathrm{mg}$ protein, while LDH activity in media was less than $10 \%$ (Table 2 and Figure $5 \mathrm{a}$ ). The $50 \mathrm{mM}$ glucose concentration increased LDH activity by almost $30 \%$ in NSC cells and three times in its culture media (Table 1 and Figure 5a). In both glucose treatment approaches, each time, the maximal/total/100\% LDH in media activity was established using NSC cultured in media with $25 \mathrm{mM}$ glucose (Supplement 1). Ultimately, the LDH in media test did not consider the impact of elevated LDH activity in the NSC cells. Therefore, the same degree of LDH leakage from NSC cells treated with $25 \mathrm{mM}$ and $50 \mathrm{mM}$ glucose ended up with significantly higher LDH in media activity in NSC cells treated with $50 \mathrm{mM}$ glucose $(p<0.01)$ (Table 1 and Figure $5 \mathrm{a}, \mathrm{b})$. The MTT test indicated $37.5 \mathrm{mM}$ and $50 \mathrm{mM}$ glucose as the glucose concentrations evoking disruption in NSC mitochondrial energy metabolism (Figure 5b). 
a
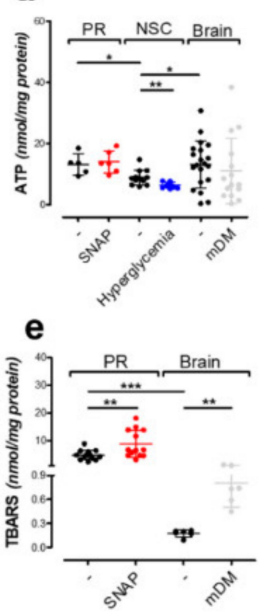

b

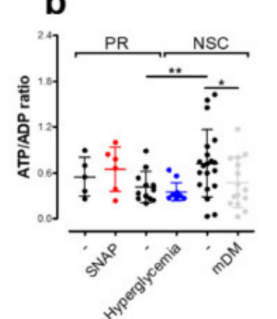

$f$
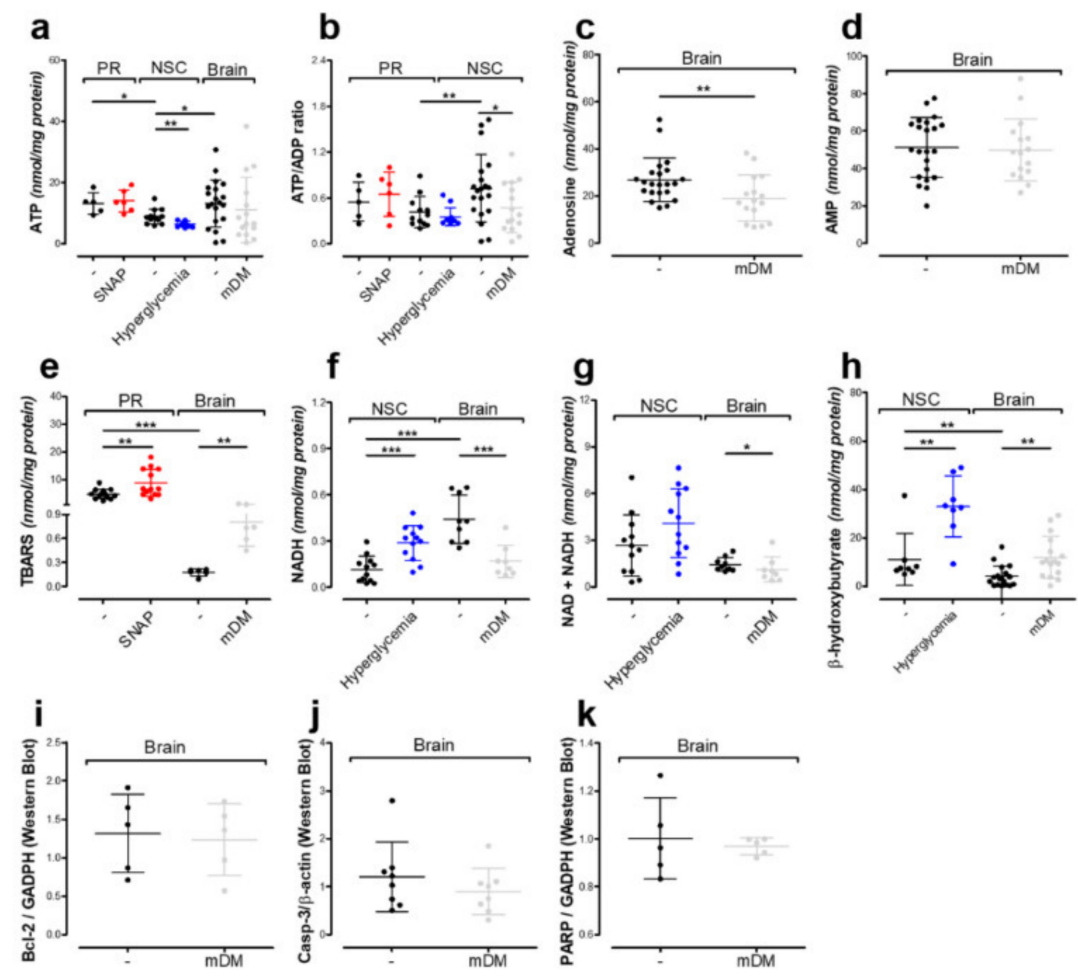

k
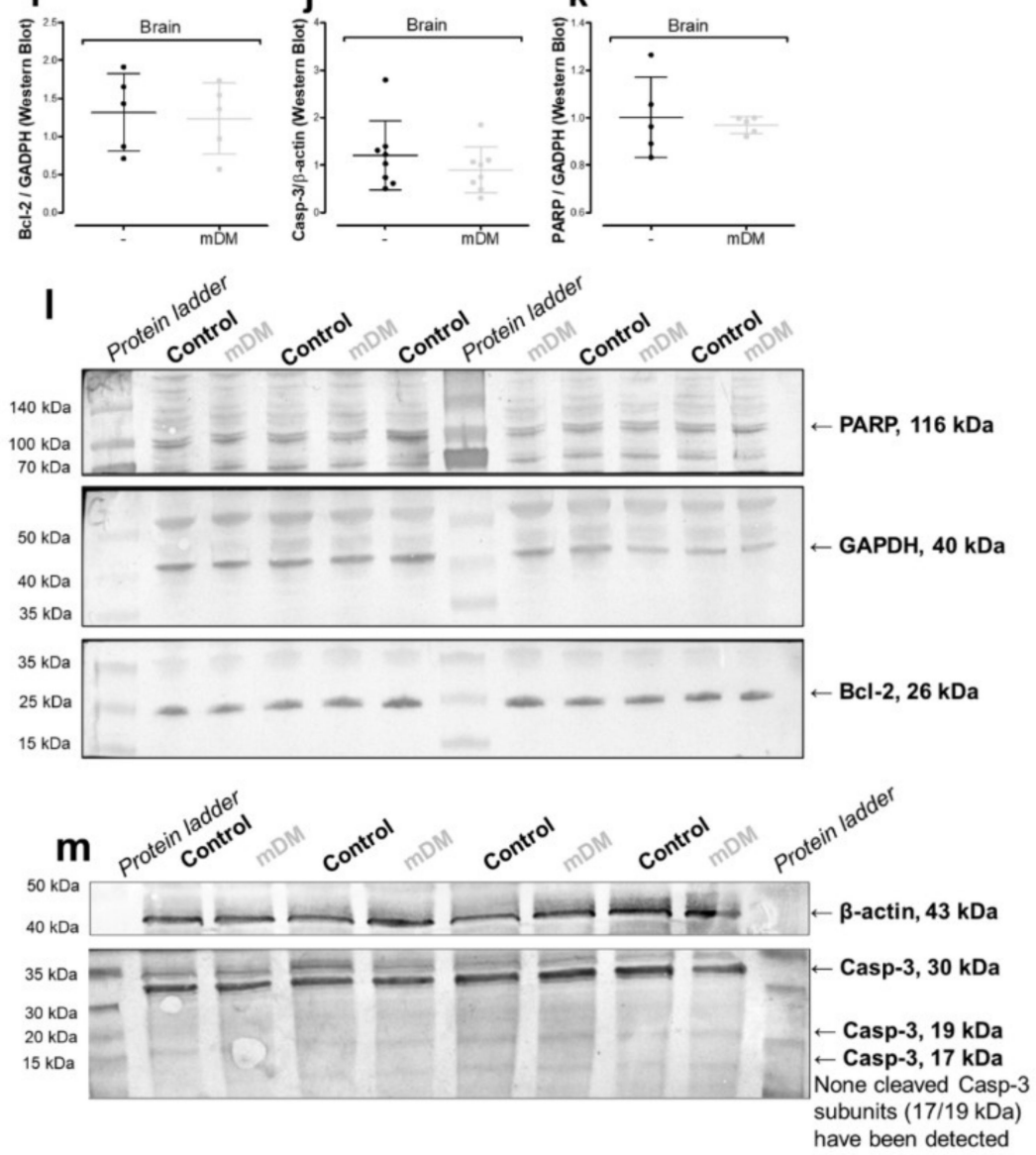

Figure 6. The impact of the toxic factors on intracellular homeostasis measured in primary neurons (PR), neural stem cells (NSC) and brain tissues (Brain). Nucleotides: (a) ATP level; (b) ATP/ADP ratio; (c) adenosine level; (d) AMP level; (f) NADH (reduced nicotinamide adenine dinucleotide) level; (g) total NAD (nicotinamide adenine dinucleotide) level. (e) TBARS level, cytosolic oxidative stress markers. (h) $\beta$-hydroxybutyrate level, ketoacidosis markers. Apoptosis markers (protein level measured by Western blot): (i) B cell lymphoma 2 (Bcl-2); (j) caspase-3 and cleaved caspase-3 (Casp-3); (k) poly-(ADP-ribose)-polymerase (PARP). Representative WB membrane images for: (1) PARP, Bcl-2, and GAPDH (glyceraldehyde 3-phosphate dehydrogenase) proteins; (m) Casp-3, cleaved Casp-3, and $\beta$-actin proteins. Data are means \pm SD from 3 to 22 observations per group. Significantly different from the control: ${ }^{*}(p$-value $<0.05),{ }^{* *}(p$-value $<0.01),{ }^{* * *}(p$-value $<0.001)$. 
Astrocytes are known to be cells, which prefer the LDH/lactate-dependent energy production pathway instead of the tricarboxylic acid cycle [36,37]. Additionally, they are the main cell type in the NSC culture, although the biochemical profile of NSC arises from all the cell types that are in this culture [19,37]. Therefore, in the NSC culture, we were able to observe changes in the lactate/pyruvate ratio resulting from interactions between glial cells and neurons (Table 2). The lactate/pyruvate ratio is especially important in diabetes. In clinical practice, the most dangerous diabetes side effect is ketoacidosis along with an increased $\mathrm{NADH} / \mathrm{NAD}$ ratio (reduced nicotinamide adenine dinucleotide/nicotinamide adenine dinucleotide ratio), which occurred in our culture system as well (Figure 6f,h). Many studies have shown that astrocytes are the only possible source of the ketone bodies produced in the brain [38-40]. Overproduced $\beta$-hydroxybutyrate can serve as an alternative source for neuronal acetyl-CoA production; therefore, no reduction of acetyl-CoA was noted in our studies (Figures 3a and 6h) [36,37]. In hyperglycemic conditions, pyruvate is overproduced in glycolysis. Next, the overproduced pyruvate either undergoes reduction by overactive LDH to lactate or enters the mitochondria to initiate the tricarboxylic acid cycle via overactive synthase citrate (Tables 1 and 2 and Figure 1) [41]. Excessive glycolysis and overactive tricarboxylic acid cycle pathways favor NAD turnover to NADH, increasing the NADH level without changes in total NAD + NADH level (Figure 6f,g). In addition, it has been reported that diabetes-related disturbances in NADH/NAD ratio might be related to an overactivation of the poly-(ADP-ribose)-polymerase (PARP) enzyme, which use NAD as a substrate [42]. However, our data showed no upregulation in the PARP protein level (Figure 6k,l).

Hyperglycemia triggered neurons to overproduce pyruvate, which is catalyzed by pyruvate dehydrogenase complex, which in theory should accelerate tricarboxylic acid turnover. However, an increased NADH/NAD ratio is an activation factor for pyruvate dehydrogenase kinase, which by the phosphorylation of PDHC prevents its over-activation (Table 1 and Figure 6f,g) [43]. As stated previously, the struggle of the ketoacidosis outcome with neurons resulted in acetyl-CoA production from an alternative pathway using $\beta$-hydroxybutyrate as a substrate; therefore, no reduction of acetyl-CoA was reported in our studies (Figures $3 \mathrm{a}$ and $6 \mathrm{~h}$ ). The overall conclusion arising from this part of the study is that the cells kept in the presence of high concentrations of glucose will have impaired energy metabolism and, probably, perturbed astrocyte-neuron coupling. This would make the model suitable for studies of the NAA network and its metabolic fragility.

\subsection{In Vivo Model of Hyperglycemia}

Our previous studies revealed that inside the cholinergic neurons, $N$-acetylaspartate production is closely related to cholinergic neurotransmission [9]. On the other hand, diabetes has been reported as a disease affecting cholinergic neurotransmission via the downregulation of cholinergic acetyltransferase [44]. Therefore, both lines were tested for choline acetyltransferase (ChAT) activity, although ChAT activity remained undetectable (NSC, data not shown) or too low to notice any important changes (primary neurons) (Figure 7a). Since our in vitro models were not sufficient for cholinergic neurotransmission studies, we analyzed the diabetic Wistar rat brains (Materials and methods). The animals had increased brain hexokinase activity, significant body weight loss, polyuria, and urinal hyperglycemia with ketoacidosis $(p<0.001)$ (Tables 1 and 3), which is consistent with other researchers' reports [45].

Table 3. General characteristics of rats used in this project.

\begin{tabular}{cccc}
\hline Parameters & Sham Control & Moderate DM & Severe DM \\
\hline Body weight $(\mathrm{g})$ & $307 \pm 33$ & $210 \pm 16^{* * *}$ & $240 \pm 50^{*}$ \\
Blood glucose $(\mathrm{mg} / \mathrm{dL})$ & $127 \pm 13$ & $513 \pm 56^{* * *}$ & $523 \pm 92^{* * *}$ \\
Urine acetoacetate $(\mu \mathrm{mol} / 24 \mathrm{~h})$ & $0.3 \pm 0.1$ & $1.9 \pm 1.0^{* *}$ & $5.8 \pm 2.4^{* * *}$ \\
\hline
\end{tabular}

Significantly different from the sham control: ${ }^{*}(p-$ value $<0.05),{ }^{* *}(p-$ value $<0.01)$ and ${ }^{* * *}(p-$ value $<0.001)$. Data are means \pm SD from 6-17 animals per group. 


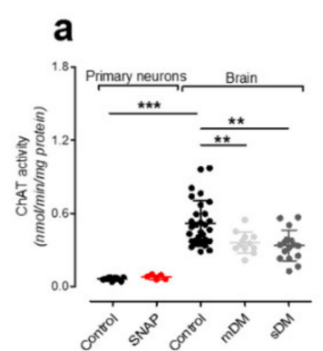

\section{b}
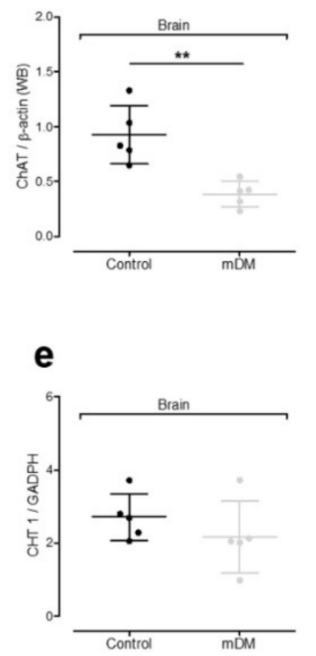
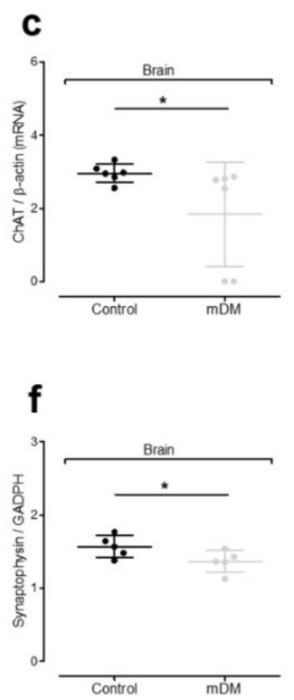

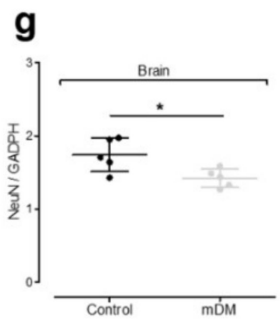

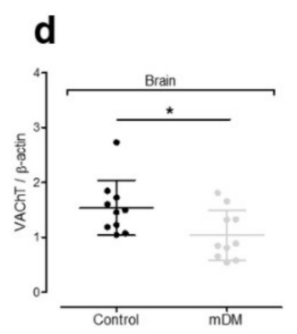
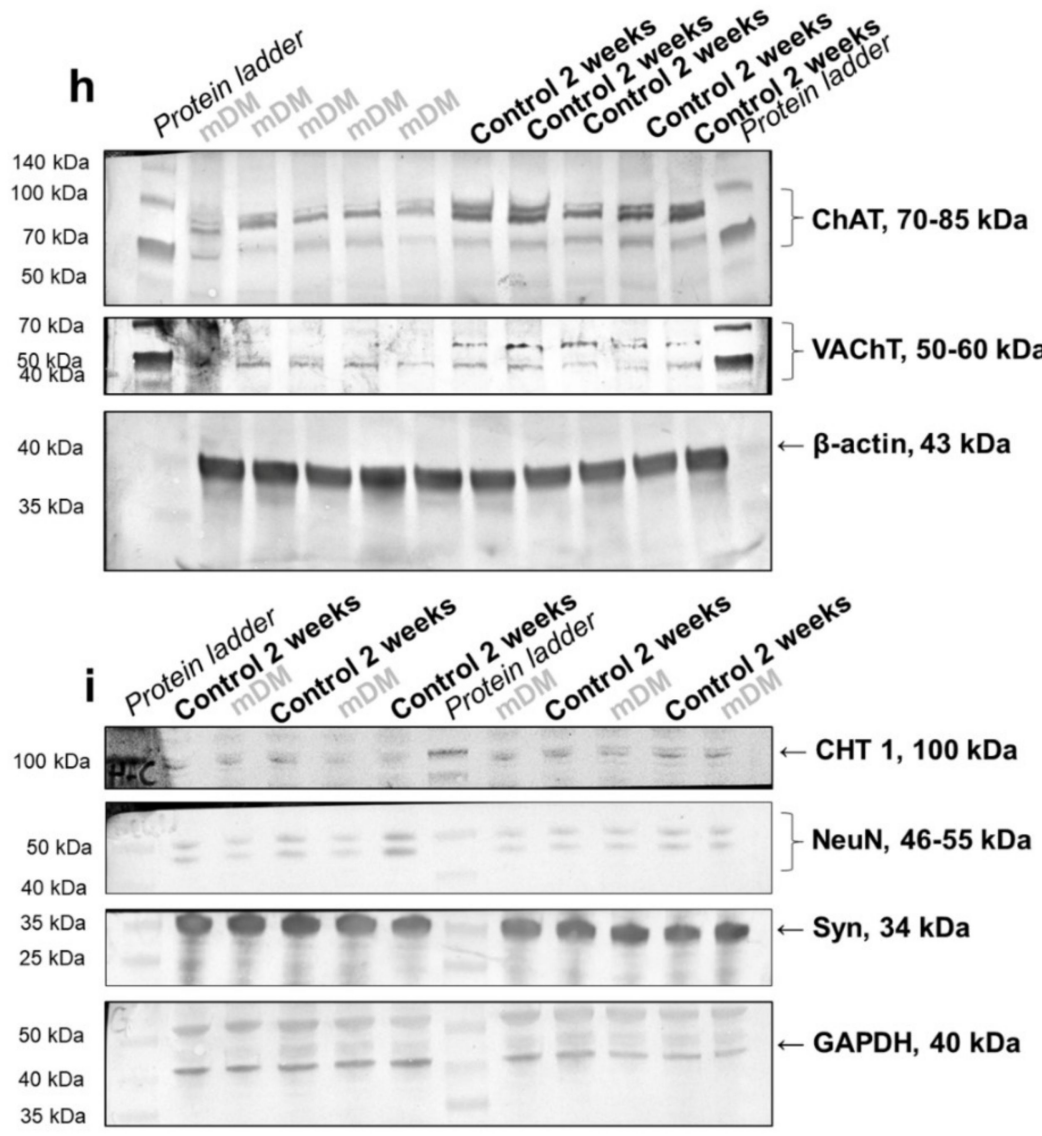

Figure 7. The impact of toxic factors on the neurotransmission markers measured in the primary neurons (PR) or the rats' brain tissues (Brain). (a) ChAT activity; (b) choline acetyltransferase (ChAT) protein level (Western blot); (c) Chat mRNA level (real-time RT-qPCR); (d) vesicular acetylcholine transporter (VAChT) protein level (Western blot); (e) high-affinity choline transporter (CHT 1) protein level (Western blot); (f) synaptophysin (Syn) protein level (Western blot); (g) NeuN protein level (Western blot); (h) representative WB membrane images for ChAT, VAChT, and $\beta$-actin proteins; (i) representative WB membrane images for CHT 1, NeuN, Syn, and GAPDH proteins. Data are means \pm SD from 3 to 16 observations per group. Significantly different from the control: ${ }^{*}(p$-value $<0.05)$, ** $(p$-value $<0.01),{ }^{* * *}(p$-value $<0.001)$. 
In cholinergic neurons, choline acetyltransferase (ChAT) introduces choline to acetyl-CoA in order to produce acetylcholine [46]. To reach the synaptic cleft, acetylcholine is carried by the vesicular acetylcholine transporter (VAChT) [46]. During ongoing neurotransmission, released acetylcholine interacts with the acetylcholine receptor co-localized with acetylcholine esterase [46]. Esterase cleaves the neurotransmitter to choline and acetate. Finally, choline returns to cholinergic neurons via the high affinity choline transporter (CHT 1) [46]. ChAT activity was significantly affected in both experimental time points ( 2 and 8 weeks as well) by the hyperglycemia-dependent downregulation of Chat gene expression $(p<0.01, p<0.01, p<0.01$, respectively) (Figure $7 \mathrm{a}-\mathrm{c}, \mathrm{h})$. This downregulation resulted in lower vesicular acetylcholine transporter (VAChT) protein levels as well (Figure $7 \mathrm{~d}, \mathrm{~h}$ ). This suggested that streptozotocin (STZ)-triggered hyperglycemia resulted in cholinergic neurons being disabled to provide fully efficient choline neurotransmission. We learned that neither the downregulation of ChAT nor VAChT affected the high-affinity choline transporter (CHT 1) protein level (Figure 7e,i). Studies with VAChT-KD ${ }^{\mathrm{H} \circ \mathrm{M}}$ transgenic mice having Vacht deficiency showed that the downregulation of VAChT does not affect either acetylcholine esterase, the muscarinic acetylcholine receptor 2, or CHT 1, either [47]. Due to the lack of the molecular studies dealing with the CHT 1 protein, this phenomenon still does not have a clear explanation. We might only assume that diminished capacity to provide cholinergic neurotransmission is not a trigger snap to modify expression of the Slc5a7 gene encoding CHT 1 (Figure 7e,i). Moreover, in the course of diabetes, apart from poor cholinergic neurotransmission, the streptozotocin-affected brains have to deal with a decreased number of $\mathrm{NeuN}(+)$ and synaptophysin $(+)$ neurons, which do not upregulate the apoptotic processes (Figure $6 \mathrm{f}, \mathrm{g}, \mathrm{i}, \mathrm{j})$. Our findings indicate that the downregulation of cholinergic neurotransmission without cell loss is consistent with the literature $[44,48,49]$. Unfortunately, no good molecular explanation has been found to fit the data. It seemed that insulin-dependent protein kinase A changes gene expression such in a way so that cholinergic markers or even neuronal maturation processes might be suppressed $[44,48,49]$.

In brain tissue, increased $\beta$-hydroxybutyrate and lactate levels confirmed ongoing lactic acidosis with ketoacidosis, while increased TBARS level as well as unchanged aconitase and isocitrate dehydrogenase activities indicated ongoing cytoplasmic oxidative stress, as well (Table 1 and Figure 6e,h). Chronic, severe hyperglycemia did not upregulate PARP protein level (the above-mentioned enzyme converts NAD to NADH) or apoptotic markers, such as cleaved caspase-3 (Casp-3) or B cell lymphoma 2 (Bcl-2) (Figure 6i-m). Considering the influence of ketoacidosis on PDHC and LDH activities as well as acetyl-CoA and pyruvate levels, we noted that chronic hyperglycemia with acidosis did not support pyruvate accumulation. However, overproduced $\beta$-hydroxybutyrate prevents acetyl-CoA shortages (Tables 1 and 2 and Figures $3 \mathrm{a}$ and $6 \mathrm{~h}$ ). The 2-week-long hyperglycemia resulted in lactic acidosis, decreasing ATP levels (Table 2 and Figure 6a).

In the brain, there is no de novo synthesis pathway for adenosine [50]. It has been shown that here, adenosine production enters the synaptic cleft from ATP produced and released by astrocytes [50]. Therefore, the ATP reduction suppressed the adenosine level as well, although other adenosine-based nucleotides remained unchanged (Figure 6a-d). The 6-day-long hyperglycemia analyzed using the NSC cells indicated a dysregulation in cellular homeostasis between NAD and NADH (Figure 6f,g). Hyperglycemia lasting for 14 days (2 weeks) in the rats' brains considerably decreased the total level of nicotinamide adenine dinucleotides, which subsequently led to a reduction of NADH level as well (Figure 6f,g). All these findings are consistent with other researchers' reports [51,52]. NSC cells reacted differently to glucose elevation than Wistar rat brains. In both models, the pyruvate dehydrogenase activity remained unchanged. In NSC cells, ketoacidosis increased pyruvate level, probably via pH-dependent LDH inhibition. Consequently, increased pyruvate levels stimulated citrate synthase activity, which overproduced citrate. These results suggest that NSC cells prioritized oxidative phosphorylation over anaerobic metabolism. In the Wistar rat brain, lactic acidosis and ketoacidosis did not change the mentioned parameter, which might indicate the development of anaerobic metabolism. In conclusion, these two models might reflect the different impact of hyperglycemia on the NAA 
network. Moreover, the in vivo model introduces the impact of cholinergic neurotransmission (and choline acetyltransferase downregulation) to the studies with NAA network fragility.

\subsection{N-Acetylaspartate Network is Resistant to NO- and Hyperglycemia-Derived Toxicity}

The $N$-acetylaspartate network (NAA network) begins inside the neurons and then ends up either in oligodendrocyte-derived myelin or in astroglial energy pathways $[2,8,13,53-56]$. Such a complicated molecular machinery is entirely controlled by one single enzyme called aspartate $N$-acetyltransferase (NAT8L, the Shati protein), which seems to be affected by dementia-related neurodegeneration processes [53,57-61]. Researchers working with Nat8l/Shati-/- knock-out mice have indicated that NAT8L might control our emotions, and that the Nat8l gene mutation promotes autism-like behavior or provokes the tendency to develop adult depression [2,13,55-61]. Moreover, clinical studies showed that maternal diabetes might increase a risk of autism spectrum disorders, which links hyperglycemia with the NAA network [62].

In the primary neuronal culture treated by exogenous nitric oxide, acetyl-CoA and aspartate levels were significantly affected ( $p<0.05$ and $p<0.01$, respectively), although the NAA level remained constant, along with NAT8L level/activity as well as NAT8L subcellular localization (Figure 3a-g). Hyperglycemia-derived acidosis together with oxidative stress jointly have been studied as a potential NAA network suppressor in neural stem cells. This time, we used an approach in which toxicity needs time to build up a noticeable pathology. Since the astroglia feed the neurons with glucose and lactate, in hyperglycemic conditions, instead of protecting neurons, astrocytes intensified neuronal pathology [34]. This time, acetyl-CoA and $\mathrm{N}$-acetylaspartate levels were not affected, although the level of aspartate was considerably decreased (Figure $5 a-c)$.

Finally, the in vivo model was used to reflect interactions between all cell types in the central nerve system (including cholinergic neurons). Two weeks after STZ injection was enough time to build up hyperglycemia-triggered toxicity affecting cholinergic neurotransmission (Figure 7a-g). To compare the impact of shorter and longer effects of ketoacidosis on the NAA network, we extended the experimental outline for an additional 6 weeks ( 8 weeks together). Each time, we noted severe energy disruption going on in the animals' brains, although the $N$-acetylaspartate level was resistant to this pathology (Figure 3c). Moreover, our data showed that neither NAT8L activity, Nat8l mRNA level, nor protein level were affected by STZ-induced hyperglycemia (Figure 3c-g).

\section{Materials and Methods}

\subsection{Materials}

Unless specified otherwise, all the used compounds were specified in Table S1, while cell culture disposables were provided by Sarstedt (Blizne, Łaszczyńskiego, Poland). Unless specified otherwise, spectrophotometric assays were run either using an Ultraspec 3100 Pro (Amersham Biosciences, Amersham, UK) or, for multiple well plates-based assays, a Victor 3, 1420 Multilabel Counter (Perkin Elmer, Warsaw, Poland).

\subsection{Ethics Approval}

All experiments were approved by the Polish Bioethics Committee (44/2016, 23 November 2016, Bydgoszcz, Poland). Studies followed the EU Directive 2010/63/EU and the International Council for Laboratory Animal Science (ICLAS) guidelines for animal experiments.

\subsection{Animals (In Vivo Studies)}

White male adult Wistar rats were housed at the Animal House (Medical University of Gdansk, Gdansk, Poland) with access to food and water ad libitum under a standard $12 \mathrm{hlight} / 12 \mathrm{~h}$ dark cycle. The rats' average weight before the experiments was 180-230 $\mathrm{g}$ followed by a weight of 200-350 $\mathrm{g}$ at the end of the experiments. 
For the purposes of this study, the animals were divided randomly into different treatment groups with the following group size: sham control group -17 male rats, moderate diabetes mellitus group -8 male rats, severe diabetes mellitus group -6 male rats.

Diabetes mellitus (DM) was induced by a single intraperitoneal injection of $65 \mathrm{mg} / \mathrm{kg}$ b.w. streptozotocin (STZ) in $0.1 \mathrm{M}$ citrate buffer (ip). The animals were sacrificed 2 weeks (moderate DM, mDM) or 8 weeks (severe DM, sDM) after injection. The sham control group was treated with a similar volume of buffer without streptozotocin.

Glycemia was measured on the third day after streptozotocin administration by serum glucose level measurement (Accu-CHEK Performa glucometer kit, Roche, Warsaw, Poland). Animals with a blood glucose $\geq 17 \mathrm{mM}$ or greater were deemed diabetic and suitable for this study (Table 3) [63]. For the last $24 \mathrm{~h}$ of in vivo experiments, the animals were transferred to a metabolic cage and $24 \mathrm{~h}$ urine samples were collected (Table 3). Before the animals were euthanized by pentobarbitone overdose ( $2 \mathrm{~mL} / \mathrm{kg}$ b.w., ip, concentration: $0.66 \mathrm{M}$ ), blood glucose level was determined (as described above).

\subsection{Primary Cultures (In Vitro Studies)}

Embryonal brain cortices (E18) obtained from pregnant Wistar rats were dissected in Hank's buffered salt solution (HBSS) supplemented by $8 \mathrm{mM}$ HEPES $(\mathrm{pH}=7.4), 100 \mathrm{U} / \mathrm{mL}$ penicillin, and streptomycin. Using different culture strategies, the cells were settled for either primary neuronal culture (PR) or neural stem cells culture (NSC) $[19,64]$.

\subsection{Embryonic Primary Neurons (PR)}

Isolated cells were seeded as a monolayer in poly-l-ornithine and laminin-coated dishes. In order to obtain mature neurons, the cells were cultured for 14 days in a neurobasal medium supplemented with

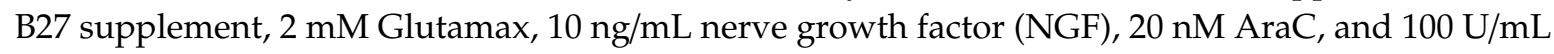
penicillin with streptomycin. Every third day of the culture, the media were changed in half of their volume. For further experiments, culture dishes were assigned randomly to different treatment experimental time points. Mature primary neurons were cultured in the same medium, although in order to study the impact of oxidative stress on the cells, the B27 supplement was changed to B27 minus antioxidant supplement. For $24 \mathrm{~h}$ after maturation, the primary neurons were cultured in the presence of 0-0.8 mM S-nitroso-N-acetylpenicillamine (SNAP). On the following day, the media were changed to fresh ones without SNAP and the cells were maintained in culture for an additional three to six days in vitro (DIV) [64].

\subsection{Embryonic Neural Stem Cells (NSC)}

Dissected cortices were cultured as neurospheres in DMEM/F12-GlutaMAX media supplemented with B27 supplement, $10 \mathrm{ng} / \mathrm{mL}$ basic fibroblast growth factor, $20 \mathrm{ng} / \mathrm{mL}$ epidermal growth factor, and $100 \mathrm{U} / \mathrm{mL}$ penicillin with streptomycin. Neurospheres were passaged every third day of culture. Cells between 1 and 3 passages were considered as suitable for this study. Neural stem cell types were recognized by $\beta$-III-tubulin (neurons), glial fibrillary acidic protein (GFAP) (astrocytes), and CNPase (2' $3^{\prime}$-Cyclic-nucleotide 3'-phosphodiesterase, oligodendrocytes) specific markers (Table S2). For the experimental step, neural stem cells (NSC) were seeded as a monolayer in poly-l-ornithine and laminin-coated dishes and left for $24 \mathrm{~h}$ in neurosphere media. To initiate cell differentiation, the cells were cultured for another 6 days in media without growth factors. For further experiments, culture dishes were assigned randomly to different treatment experimental time points. Here, NSC cells grew in media with $25-75 \mathrm{mM}$ glucose and supplement B27 minus antioxidants instead of the standard B27 supplement. In order to replenish the glucose level, the media were changed each day of the culture [19]. 


\subsection{Sample Preparation}

Brain tissues (without cerebellum) or cells were homogenized in chilled: $4 \% \mathrm{HClO} 4$ (for metabolic studies); $0.1 \mathrm{M} \mathrm{HCl}$ (for NAD assay); $0.2 \mathrm{M} \mathrm{KOH}$ (for NADH assay); or $0.32 \mathrm{M}$ sucrose buffered by $5 \mathrm{mM}$ HEPES ( $\mathrm{pH}=7.4$ ) with $0.1 \mathrm{mM}$ EDTA (ethylenediaminetetraacetic acid, for enzymatic assays). After centrifugation at $13,000 \times g\left(4{ }^{\circ} \mathrm{C}, 15 \mathrm{~min}\right)$, each sample was immediately used for studies or kept at $-80^{\circ} \mathrm{C}$ until analyzed.

\subsection{Morphology Imaging}

Images were captured under 40× magnification using an inverted light microscope (Axiovert 25, Zeiss) [9].

\subsection{Enzymatic Assays}

To analyze enzymatic activity in the cell lines, from each dish, two independent cell lysates were collected and reported as one average result. To analyze enzymatic activity in brain tissue, 3 tissue lysates per one brain were collected, and then, the enzymatic profile of each lysate was measured in two independent samples. Eventually, 3 average results per 1 brain were reported in this study. Protocols for enzymatic assays were described with details in our previous study [25].

Aconitase (Aco, EC 4.2.1.3) [25], aspartate aminotransferase (GOT, EC 2.6.1.1) [25], aspartate $\mathrm{N}$-acetyltransferase (NAT8L, EC 2.3.1.17) [25], citrate synthase (SC, EC 2.3.3.1) [25], choline acetyltransferase (ChAT, EC 2.3.1.6) [25], isocitrate dehydrogenase (IDH, EC 1.1.1.42) [25], pyruvate dehydrogenase complex (PDHC, EC 1.2.4.1) [25].

Hexokinase (Hex, EC 2.7.1.1) activity was determined using the NADPH/NADP conversion technique at $\lambda=340 \mathrm{~nm}$ and $37^{\circ} \mathrm{C}$. Then, $1 \mathrm{~mL}$ of reaction buffer contained $0.1 \mathrm{M}$ Tris- $\mathrm{HCl}(\mathrm{pH}=7.4)$, $5 \mathrm{mM}$ glucose, $0.2 \mathrm{mM} \mathrm{MgCl}_{2}, 0.25 \mathrm{mM}$ NADH, $1 \mathrm{U}$ glucose-6-phosphate dehydrogenase (G-6-PDH, EC 1.1.1.49), and $20 \mu \mathrm{g}$ of cell homogenate protein. Enzymatic assay was initiated by the addition of $10 \mu \mathrm{L}$ of $0.1 \mathrm{M}$ ATP [65].

Lactate dehydrogenase or LDH in media assay (LDH, EC 1.1.1.27) activity was determined using the NADH/NAD conversion technique, at $\lambda=340 \mathrm{~nm}$ and $37^{\circ} \mathrm{C}$. Then, $1 \mathrm{~mL}$ of reaction buffer contained $0.1 \mathrm{M}$ Tris- $\mathrm{HCl}(\mathrm{pH}=7.4), 0.2 \mathrm{mM} \mathrm{NADH}$, and $20 \mu \mathrm{g}$ of cell homogenate protein (or 0-200 $\mu \mathrm{L}$ of culture media, for cell viability test assay). Enzymatic assay was initiated by the addition of $10 \mu \mathrm{L}$ of 0.1 M pyruvate [66].

Pyruvate dehydrogenase complex (PDHC, EC 1.2.4.1.) activity was determined using cycling method. In each lysate (100 $\mu \mathrm{g}$ of cell homogenate protein), the following reactions were performed: (1) citrate production and (2) citrate level measurement. The first reaction (1) was carried out in $250 \mu \mathrm{L}$ for $30 \mathrm{~min}\left(37^{\circ} \mathrm{C}\right.$, gentle shaking), the buffer contained $0.1 \mathrm{M}$ Tris- $\mathrm{HCl}(\mathrm{pH}=8.3), 2 \mathrm{mM} \mathrm{MgCl}, 10 \mathrm{mM}$ dithiothreitol, $10 \mathrm{mM}$ pyruvate, $2 \mathrm{mM}$ thiamine pyrophosphate, $0.2 \mathrm{mM} \mathrm{CoA}, 2.5 \mathrm{mM}$ oxaloacetate, $2 \mathrm{mM} \mathrm{NAD}$, and $0.15 \mathrm{U}$ citrate synthase (EC 4.1.3.7). Reaction was terminated by thermic shock (10 min, $100^{\circ} \mathrm{C}$ ). Finally, the produced citrate level was determined using NADH/NAD conversion technique at $\lambda=340 \mathrm{~nm}$ and $37^{\circ} \mathrm{C}$. The reaction buffer contained $0.1 \mathrm{M}$ Tris- $\mathrm{HCl}(\mathrm{pH}=7.4), 0.1 \mathrm{mM} \mathrm{NADH}, 0.2 \mathrm{U}$ malate dehydrogenase (EC 1.1.1.37), and $100 \mu \mathrm{L}$ of achieved supernatant in a final volume of $0.7 \mathrm{~mL}$. The assay was initiated by the addition of $10 \mu \mathrm{L}$ of $0.1 \mathrm{U}$ citrate lyase (EC 4.1.3.6). The blank sample was treated in the same way as the measured sample, but the blank sample was not reached in CoA [67].

\subsection{Metabolic Assays}

To analyze metabolic profiles, we collected two independent acidic supernatants per each cell culture dish or three independent acidic supernatants per one rat brain. After $15 \mathrm{~min}$ of deproteinization (at $4{ }^{\circ} \mathrm{C}$ ), samples were centrifuged at $13,000 \times g\left(4{ }^{\circ} \mathrm{C}, 15 \mathrm{~min}\right)$. Next, ice-cold samples were neutralized and immediately assayed. 
Protocols for acetoacetate, acetyl-CoA, aspartate, $\beta$-hydroxybutyrate, lactate, $N$-acetylaspartate, oxaloacetate, pyruvate, and TBARS assays were described with details in our previous study [25].

Protocols for ATP and ADP, AMP, adenosine [68], citrate [67], the MTT viability test [41], nitric oxide (DAF-2 staining) [69], Griess assay [70]), NAD, and NADH [71] assays are described with details in Supplement 1.

\subsection{Real-Time RT-qPCR Analysis of Nat8l and Chat mRNA Levels}

The $2 \times 10^{6}$ cells or $0.1 \mathrm{~g}$ of brain tissues were vortexed or homogenized in a sterile tube with $0.5 \mathrm{~mL}$ (cells) or $1 \mathrm{~mL}$ (brain tissue) of RNA Extracol extraction buffer (Eurx, Cat \#E3700-02, Gdansk, Poland). The extraction was initiated by the addition of $250 \mu \mathrm{L}$ chloroform (per $1 \mathrm{~mL}$ of RNA Extracol buffer). After vigorous shaking, each sample was incubated at $4{ }^{\circ} \mathrm{C}$ for $15 \mathrm{~min}$ and spun down $(10,000 \times g$ for $15 \mathrm{~min}$ at $4{ }^{\circ} \mathrm{C}$ ). The upper aqueous phase was transferred to a new tube and refilled by isopropanol in a 1:2 ratio (isopropanol: RNA Extracol, $v / v$ ). The RNA precipitation was carried out overnight at $-20^{\circ} \mathrm{C}$, and on the following day, each sample was centrifuged $\left(10,000 \times g\right.$ for $15 \mathrm{~min}$ at $\left.4{ }^{\circ} \mathrm{C}\right)$. The RNA pellet was washed firstly with $99.8 \%$ and then with $75 \%$ ethanol, finally air-dried, and reconstituted in nuclease-free water (15-20 $\mu \mathrm{L}$ ) (Sigma Aldrich, Cat\# W4502, Poznań, Poland). The obtained samples were kept at $-20^{\circ} \mathrm{C}$ until analyzed. The quantity of isolated RNA was determined using the Qubit RNA HA assay kit according to the manufacturer's instructions (ThermoFisher Sc., Cat \#Q32855, Warsaw, Poland). The gene expression levels of Nat8l encoding the NAT8L enzyme and Chat encoding the ChAT enzyme were determined by real-time RT-qPCR performed in a Light Cycler 480 II (Roche Diagnostic GmbH, Penzberg, Germany) using a Path-IDTM Multiplex One-Step RT-PCR Kit (ThermoFisher Sc., Cat \#4442135, Warsaw, Poland) and Universal ProbeLibrary for the rat species, and gene-specific intron-spanning primers (Table 4). The reaction mixture in the final volume $10 \mu \mathrm{L}$ contained $5 \mu \mathrm{L}$ of Multiplex RT-PCR Buffer, $1 \mu \mathrm{L}$ of Multiplex Enzyme Mix, and $0.5 \mu \mathrm{L}$ of each primer for the target transcript, $0.2 \mu \mathrm{L}$ of a target probe, $0.2 \mu \mathrm{L}$ of primers' reference gene, $0.2 \mu \mathrm{L}$ of a probe for the reference transcript, and $2 \mu \mathrm{L}$ of total RNA (Table 4). The target gene transcript levels were normalized to the reference transcript of the $\beta$-actin gene $(A c t b)$. Reverse transcription program: $48^{\circ} \mathrm{C}-10 \mathrm{~min}$ and $95^{\circ} \mathrm{C}-10 \mathrm{~min}$. Amplification program: $95^{\circ} \mathrm{C}-15 \mathrm{~s}, 60^{\circ} \mathrm{C}-45 \mathrm{~s}$ for 45 cycles. Data were processed with Light Cycler 480 II software 2.0 [25].

Table 4. A list of primers and TaqMan probes used in this project.

\begin{tabular}{|c|c|c|c|}
\hline Gene Transcript & Primers & TaqMan Probe & $\begin{array}{c}\text { Transcript of } \\
\text { Reference Gene }\end{array}$ \\
\hline Nat8l NM_001191681.1 & $\begin{array}{l}\text { (F) tggctgacattgaacagtactaca } \\
\text { (R) cacaacattgccgtccag }\end{array}$ & $\begin{array}{c}\text { Universal ProbeLibrary } \\
\text { Probe \#83 (Roche, Cat } \\
\text { \#04689062001) }\end{array}$ & $\begin{array}{c}\text { Universal ProbeLibrary Rat } \\
\text { Actb Gene Assay }\end{array}$ \\
\hline Chat NM_001170593.1 & $\begin{array}{l}\text { (F) gaagcttccaagccactttc } \\
\text { (R) gtagtagagcctcagacgacgac }\end{array}$ & $\begin{array}{c}\text { Universal ProbeLibrary } \\
\text { Probe \#66 (Roche, Cat } \\
\text { \#04688651001) }\end{array}$ & (Roche, Cat \#05046203001) \\
\hline
\end{tabular}

\subsection{Double Staining in Immunocytochemistry}

For immunocytochemistry, cells were seeded on cover slips and cultured as usual. Next, the cells were fixed with $4 \%$ paraformaldehyde in sterile PBS $(\mathrm{pH}=7.4,15 \mathrm{~min}$, room temperature) followed by 3 washes with PBS. The fixed cells were left in PBS at $4{ }^{\circ} \mathrm{C}$ until needed. Before immunostaining, the cells were permeabilized for $30 \mathrm{~min}$ in PBS buffer with $0.1 \%$ Triton X-100 and 5\% bovine serum albumin. The overnight incubation of cover slips was carried out in $0.1 \%$ Triton $/ 0.5 \%$ bovine serum albumin/PBS and two primary antibodies diluted to 1:200 (v/v) with two different hosts (Table 5). On the following day, the cover slips were washed 3 times in PBS and then incubated for $3 \mathrm{~h}$ in PBS buffer with $0.1 \%$ Triton, $0.5 \%$ bovine serum albumin, and two Alexa Fluor ${ }^{\circledR}$-conjugated secondary antibodies $(1: 500, v / v)$ (Table 5). Finally, the cover slips were incubated for $5 \mathrm{~min}$ with $0.2 \mu \mathrm{M}$ DAPI ( $4^{\prime}, 6$-diamidyno-2-fenyloindol) in PBS buffer with $0.1 \%$ Triton and $0.5 \%$ bovine serum albumin. After an 
additional 3 washes in PBS, the cover slips were mounted with ProLong ${ }^{\mathrm{TM}}$ Glass Antifade Mountant (ThermoFisher Sc., Cat \#P36980). Images were captured under 60x magnification using an inverted fluorescence microscope (Olympus IX83, Olympus) [72].

Table 5. A list of antibodies used in this project.

\begin{tabular}{|c|c|c|c|}
\hline Target Protein & Type of Antibody & Company & Cat\# \\
\hline$\beta$-actin & mouse primary monoclonal & Sigma Aldrich & A2228 \\
\hline NAT8L & rabbit primary polyclonal & Thermo Fisher Sc. & PA5-49536 \\
\hline $\mathrm{Bcl}-2$ & rabbit primary polyclonal & Abcam & Ab59348 \\
\hline$\beta$-III-tubulin & rabbit primary monoclonal & Cell Signaling & $5568 \mathrm{~T}$ \\
\hline Caspase-3 & rabbit primary polyclonal & Cell Signaling & $9662 \mathrm{~s}$ \\
\hline ChAT & rabbit primary polyclonal & MyBioSource & MBS127981 \\
\hline CNPase & mouse primary monoclonal & Sigma Aldrich & C5922 \\
\hline GFAP & rabbit primary polyclonal & DAKO & Z0334 \\
\hline GAPDH & mouse primary monoclonal & Abcam & ab8245 \\
\hline Goat IgG & $\begin{array}{l}\text { rabbit secondary polyclonal } \\
\text { AP-conjugated }\end{array}$ & Sigma Aldrich & A4187 \\
\hline CHT-1 & rabbit primary polyclonal & MyBioSource & MBS129733 \\
\hline Mouse IgG & $\begin{array}{c}\text { goat secondary polyclonal } \\
\text { AP-conjugated }\end{array}$ & Sigma Aldrich & A3562 \\
\hline Mouse IgG1 & $\begin{array}{c}\text { goat secondary polyclonal } \\
488 \text {-conjugated }\end{array}$ & Thermo Fisher Sc. & A21121 \\
\hline NeuN & rabbit primary monoclonal & Cell Signaling & $24307 \mathrm{~T}$ \\
\hline nAChR & rabbit primary polyclonal & Santa Cruz SCBT & sc-5591 \\
\hline PARP & rabbit primary polyclonal & Millipore & AB16661 \\
\hline Rabbit IgG & $\begin{array}{l}\text { goat secondary polyclonal } \\
\text { AP-conjugated }\end{array}$ & Santa Cruz SCBT & sc-2007 \\
\hline Rabbit IgG & $\begin{array}{c}\text { goat secondary polyclonal } \\
555-\text { conjugated }\end{array}$ & Thermo Fisher Sc. & A21428 \\
\hline Synaptophysin & rabbit primary polyclonal & Abcam & ab14692 \\
\hline VAChT & goat primary polyclonal & Thermo Fisher Sc. & OSG00003W \\
\hline
\end{tabular}

\subsection{Western Blot Analysis}

The brain tissue samples were lysed for $30 \mathrm{~min}$ in lysis buffer (1\% protease inhibitor cocktail, $50 \mathrm{mM}$ Tris- $\mathrm{HCl}$ buffer pH 7.4, $5 \mathrm{mM}$ EDTA, $100 \mathrm{mM} \mathrm{NaCl}, 1 \%$ Triton-X100, 5\% glycerol, $10 \mathrm{mM}$ $\left.\mathrm{KH}_{2} \mathrm{PO}_{4}\right)$ at $4{ }^{\circ} \mathrm{C}$. The obtained lysates were kept at $-20{ }^{\circ} \mathrm{C}$ until analysis. Each sample $(40 \mu \mathrm{g}$ of protein/20 $\mu \mathrm{L}$ of $10 \mathrm{mM}$ dithiothreitol/Laemmli buffer) was incubated for $1 \mathrm{~h}$ at $57^{\circ} \mathrm{C}$ followed by the addition of $2 \mu \mathrm{L} 0.5 \mathrm{M}$ 2-chloroacetamide and incubation for an additional $1 \mathrm{~h}$ at room temperature. Next, the spun down samples $\left(10,000 \times g\right.$ for 2 min at $\left.4{ }^{\circ} \mathrm{C}\right)$ were loaded to ExpressPlus ${ }^{\text {TM }}$ PAGE Gel 4-20\% gradient BisTris-PAGE gels (GenSignal, Cat \#GS1960, Warsaw, Poland). Then, the BisTris-PAGE gel was run at $300 \mathrm{~V}$ for $17 \mathrm{~min}$ in MOPS/SDS running buffer ( $1 \mathrm{M}$ Tris $\mathrm{pH}=7.7,1 \mathrm{M}$ MOPS, $70 \mathrm{mM}$ SDS, $20.5 \mathrm{mM}$ EDTA) in a MINI-PROTEAN electrophoresis system with cooling (Roche, Warsaw, Poland). Next, proteins were transferred from the Bis Tris-PAGE gel to a PVDF membrane (pore size: $0.2 \mu \mathrm{m}$, iBlot ${ }^{\circledR}$ transfer stack, Cat \#IB401001, Warsaw, Poland) using the iBlot ${ }^{\circledR}$ Dry Blotting System with P0 program (program details: 1 min-20 V, 4 min-23 V, 3 min-25 V) (ThermoFisher Sc., Dreieich, Germany). The PVDF membrane was washed $2 \times 10 \mathrm{~min}$ in TBTS buffer $(25 \mathrm{mM}$ Tris- $\mathrm{HCl} \mathrm{pH}=7.4$, $135 \mathrm{mM} \mathrm{NaCl}, 3 \mathrm{mM} \mathrm{KCl}, 0.5 \%$ Tween20). Non-specific bindings were blocked with 5\% BSA in TBST (60 min, room temperature). Next, the PVDF membrane was incubated with specific primary antibodies $(1: 500, v / v)$ in $5 \%$ BSA/TBST buffer $\left(4^{\circ} \mathrm{C}\right.$, overnight) (Table 5). On the following day, after $4 \times 10 \mathrm{~min}$ washing, the membrane was incubated with polyclonal AP-conjugated secondary antibodies diluted 1:5000 $(v / v)$ with $5 \%$ BSA/TBST buffer ( $3 \mathrm{~h}$, room temperature) (Table 5). The PVDF membrane was developed in a dark room for 15 min with developing buffer $(0.1 \mathrm{M}$ Tris buffer $\mathrm{pH}=9.5,0.1 \mathrm{M} \mathrm{NaCl}$, $5 \mathrm{mM} \mathrm{MgCl} 2,0.33 \mathrm{mg} / \mathrm{mL}$ nitrotetrazolium Blue chloride, and $0.17 \mathrm{mg} / \mathrm{mL}$ BCIP) [72]. 


\subsection{Protein Assay}

Protein was assayed as previously [25].

\subsection{Statistics}

The results are presented as a means \pm standard deviation of the mean (SD). The Kolmogorov-Smirnov normality test excluded normal data distribution. Therefore, the results were tested by either the Mann-Whitney test or Kruskal-Wallis followed by Dunn's Multiple Comparison post-test, where values of $p<0.05$ were considered statistically significant. We performed all statistical analyses using the Graph Pad Prism 4.0 statistical package (Graph Pad Software, San Diego, CA, USA).

\section{Conclusions}

The $\mathrm{N}$-acetylaspartate network is created by a reaction between acetyl-CoA and aspartate metabolites introduced by aspartate $N$-acetylaspartate (NAT8L), while cholinergic neurotransmission starts from the reaction between acetyl-CoA and choline catalyzed by choline acetyltransferase. Our data clearly show that type 1 diabetes-like conditions triggers disturbances in energy metabolism. Under these conditions, brain cells kept the $\mathrm{N}$-acetylaspartate level and NAT8L activity stable, but cholinergic markers were downregulated. In our previous study, we showed that the progression of Alzheimer disease-associated cholinergic neurodegeneration accompanied the NAT8L inhibition. The same pattern was identified in type 1 diabetes patients. Thus, we conclude that these diseases share pathomechanisms that trigger $\mathrm{N}$-acetylaspartate depletion by the inhibition of NAT8L gene expression or enzyme activity rather than by substrate shortages.

Supplementary Materials: Supplementary materials can be found at http://www.mdpi.com/1422-0067/21/22/ $8541 / s 1$.

Author Contributions: All authors had full access to all the data in the study and take responsibility for the integrity of the data and the accuracy of the data analysis: Conception: M.Z.; Methodology: M.Z., P.P., R.K. and M.S.-B.; Investigation: M.Z., P.P., R.K., M.S.-B. and K.L.; Formal Analysis: M.Z., M.S.-B.; Resources: M.Z., M.S.-B. and R.K.; Writing Original Draft: M.Z. and M.S.-B.; Visualization: M.Z. Supervision: T.P.; Funding acquisition: M.Z. and R.K. All authors have read and agreed to the published version of the manuscript.

Funding: This work was supported by the Ministry of Research and Higher Education (MN001 -0340/08/248 and 01-313/08/525), National Science Center (2015/17/N/NZ3/01428) projects.

Acknowledgments: The authors wish to extend their appreciation to colleagues from the Department of Laboratory Medicine (Medical University of Gdansk) who kindly gave permission to use their research facility.

Conflicts of Interest: The authors declare no conflict of interest.

\section{Abbreviations}

$\begin{array}{ll}\text { Aco } & \text { Aconitase } \\ \text { AspAT } & \text { Aspartate aminotransferase } \\ \text { b.w. } & \text { Body weight } \\ \text { Casp-3 } & \text { Caspase-3 } \\ \text { ChAT } & \text { Choline acetyltransferase protein } \\ \text { Chat } & \text { Choline acetyltransferase gene } \\ \text { CHT1 } & \text { High affinity choline transporter } \\ \text { CNPase } & \text { 2', } 3^{\prime} \text {-cyclic-nucleotide } 3^{\prime} \text {-phosphodiesterase } \\ \text { DIV } & \text { Days in vitro } \\ \text { DM } & \text { Diabetes mellitus } \\ \text { GFAP } & \text { Glial fibrillary acidic protein } \\ \text { IDH } & \text { Isocitrate dehydrogenase } \\ \text { LDH } & \text { Lactate dehydrogenase } \\ \text { mDM } & \text { Moderate diabetes mellitus } \\ \text { MTT } & \text { Methylthiazolyldiphenyl-tetrazolium bromide } \\ \text { NAA } & \text { N-acetylaspartate }\end{array}$


NAT8L Aspartate $N$-acetyltransferase protein

Nat8l N-acetyltransferase 8 Like gene

NO Nitric oxide

NSC Neural stem cells

PDHC Pyruvate dehydrogenase complex

SC Citrate synthase

sDM Severe diabetes mettilus

SNAP S-Nitroso- $N$-acetylpenicillamine

STZ Streptozotocin

TBARS Thiobarbituric acid reactive substances

VAChT Vasicular acetylcholine transporter

\section{References}

1. Ariyannur, P.S.; Madhavarao, C.N.; Namboodiri, A.M. N-acetylaspartate synthesis in the brain: Mitochondria vs. microsomes. Brain Res. 2008, 1227, 34-41. [CrossRef] [PubMed]

2. Ariyannur, P.S.; Moffett, J.R.; Manickam, P.; Pattabiraman, N.; Arun, P.; Nitta, A.; Nabeshima, T.; Madhavarao, C.N.; Namboodiri, A.M.A. Methamphetamine-induced neuronal protein NAT8L is the NAA biosynthetic enzyme: Implications for specialized acetyl coenzyme A metabolism in the CNS. Brain Res. 2010, 1335, 1-13. [CrossRef] [PubMed]

3. Arun, P.; Madhavarao, C.N.; Moffett, J.R.; Namboodiri, M.A. Regulation of N-acetylaspartate and $\mathrm{N}$-acetylaspartylglutamate biosynthesis by protein kinase activators. J. Neurochem. 2006, 98, 2034-2042. [CrossRef] [PubMed]

4. Arun, P.; Moffett, J.R.; Namboodiri, A.M. Evidence for mitochondrial and cytoplasmic N-acetylaspartate synthesis in SH-SY5Y neuroblastoma cells. Neurochem. Int. 2009, 55, 219-225. [CrossRef]

5. Baslow, M.H. Canavan's spongiform leukodystrophy: A clinical anatomy of a genetic metabolic CNS disease. J. Mol. Neurosci. 2000, 15, 61-69. [CrossRef]

6. Clark, J.B. N-acetyl aspartate: A marker for neuronal loss or mitochondrial dysfunction. Dev. Neurosci. 1998, 20, 271-276. [CrossRef]

7. Demougeot, C.; Garnier, P.; Mossiat, C.; Bertrand, N.; Giroud, M.; Beley, A.; Marie, C. N-Acetylaspartate, a marker of both cellular dysfunction and neuronal loss: Its relevance to studies of acute brain injury. J. Neurochem. 2001, 77, 408-415. [CrossRef]

8. Wiame, E.; Tyteca, D.; Pierrot, N.; Collard, F.; Amyere, M.; Noel, G.; Desmedt, J.; Nassogne, M.C.; Vikkula, M.; Octave, J.O.; et al. Molecular identification of aspartate $\mathrm{N}$-acetyltransferase and its mutation in hypoacetylaspartia. Biochem. J. 2010, 425, 127-136. [CrossRef]

9. Zyśk, M.; Bielarczyk, H.; Gul-Hinc, S.; Dyś, A.; Gapys, B.; Ronowska, A.; Sakowicz-Burkiewicz, M.; Szutowicz, A. Phenotype-Dependent Interactions between N-acetyl-L-Aspartate and Acetyl-CoA in Septal SN56 Cholinergic Cells Exposed to an Excess of Zinc. J. Alzheimers Dis. 2017, 56, 1145-1158. [CrossRef]

10. Baslow, M.H. Functions of N-acetyl-L-aspartate and N-acetyl-L-aspartylglutamate in the vertebrate brain: Role in glial cell-specific signaling. J. Neurochem. 2000, 75, 453-459. [CrossRef]

11. Bates, T.E.; Strangward, M.; Keelan, J.; Davey, G.P.; Munro, P.M.; Clark, J.B. Inhibition of N-acetylaspartate production: Implications for 1H MRS studies in vivo. Neuroreport 1996, 7, 1397-1400. [CrossRef] [PubMed]

12. Chakraborty, G.; Mekala, P.; Yahya, D.; Wu, G.; Ledeen, R.W. Intraneuronal N-acetylaspartate supplies acetyl groups for myelin lipid synthesis: Evidence for myelin-associated aspartoacylase. J. Neurochem. 2001, 78, 736-745. [CrossRef] [PubMed]

13. Dautry, C.; Vaufrey, F.; Brouillet, E.; Bizat, N.; Henry, P.G.; Condé, F.; Bloch, G.; Hantray, P. Early N-acetylaspartate depletion is a marker of neuronal dysfunction in rats and primates chronically treated with the mitochondrial toxin 3-nitropropionic acid. J. Cereb. Blood Flow Metab. 2000, 20, 789-799. [CrossRef] [PubMed]

14. Di Pietro, V.; Amorini, A.M.; Tavazzi, B.; Vagnozzi, R.; Logan, A.; Vagnozzi, R.; Logan, A.; Lazzarino, G.; Signoretti, S.; Lazzarino, G.; et al. The molecular mechanisms affecting N-acetylaspartate homeostasis following experimental graded traumatic brain injury. Mol. Med. 2014, 20, 147-157. [CrossRef] [PubMed]

15. Igarashi, H.; Suzuki, Y.; Huber, V.J.; Nakada, T. N-acetylaspartate decrease in acute stage of ischemic stroke: A perspective from experimental and clinical studies. Magn. Reson. Med. Sci. 2015, 14, 13-24. [CrossRef] 
16. Mangia, S.; Kumar, A.F.; Moheet, A.A.; Roberts, R.J.; Eberly, L.E.; Seaquist, E.R.; Tkáč, I. Neurochemical profile of patients with type 1 diabetes measured by 1H-MRS at 4 T. J. Cereb. Blood Flow Metab. 2013, 33, 754-759. [CrossRef]

17. Wrighten, S.A.; Piroli, G.G.; Grillo, C.A.; Reagan, L.P. A look inside the diabetic brain: Contributors to diabetes-induced brain aging. Biochim. Biophys. Acta Mol. Basis Dis. 2009, 1792, 444-453. [CrossRef]

18. Heikkilä, O.; Lundbom, N.; Timonen, M.; Groop, P.H.; Heikkinen, S.; Mäkimattila, S. Hyperglycaemia is associated with changes in the regional concentrations of glucose and myo-inositol within the brain. Diabetologia 2009, 52, 534-540. [CrossRef]

19. Söllvander, S.; Nikitidou, E.; Gallasch, L.; Zyśk, M.; Söderberg, L.; Sehlin, D.; Lannfelt, L.; Erlandsson, A. The $\mathrm{A} \beta$ protofibril selective antibody mAb158 prevents accumulation of $\mathrm{A} \beta$ in astrocytes and rescues neurons from A $\beta$-induced cell death. J. Neuroinflam. 2018, 15, 98. [CrossRef]

20. Szutowicz, A.; Bielarczyk, H.; Jankowska-Kulawy, A.; Pawełczyk, T.; Ronowska, A. Acetyl-CoA the key factor for survival or death of cholinergic neurons in course of neurodegenerative diseases. Neurochem. Res. 2013, 38, 1523-1542. [CrossRef]

21. Szutowicz, A.; Bielarczyk, H.; Ronowska, A.; Gul-Hinc, S.; Klimaszewska-Łata, J.; Dyś, A.; Zyśk, M.; Pawełczyk, T. Intracellular redistribution of acetyl-CoA, the pivotal point in differential susceptibility of cholinergic neurons and glial cells to neurodegenerative signals. Biochem. Soc. Trans. 2014, 42, 1101-1106. [CrossRef] [PubMed]

22. Halim, N.D.; McFate, T.; Mohyeldin, A.; Okagaki, P.; Korotchkina, L.G.; Patel, M.S.; Jeoung, N.H.; Harris, R.A.; Schell, M.J.; Verma, A. Phosphorylation status of pyruvate dehydrogenase distinguishes metabolic phenotypes of cultured rat brain astrocytes and neurons. GLIA 2010, 58, 1168-1176. [CrossRef] [PubMed]

23. Jha, M.K.; Jeon, S.; Suk, K. Pyruvate dehydrogenase kinases in the nervous system: Their principal functions in neuronal-glial metabolic interaction and neuro-metabolic disorders. Curr. Neuropharmacol. 2012, 10, 393-403. [PubMed]

24. Stacpoole, P.W. Therapeutic Targeting of the Pyruvate Dehydrogenase Complex/Pyruvate Dehydrogenase Kinase (PDC/PDK) Axis in Cancer. J. Natl. Cancer. Inst. 2017, 109. [CrossRef] [PubMed]

25. Zyśk, M.; Sakowicz-Burkiewicz, M.; Pikul, P.; Kowalski, R.; Michno, A.; Pawełczyk, T. The impact of acetyl-CoA and aspartate shortages on the $\mathrm{N}$-acetylaspartate level in different models of cholinergic neurons. Antioxidants 2020, 13, 522. [CrossRef]

26. Adela, R.; Nethi, S.K.; Bagul, P.K.; Barui, A.K.; Mattapally, S.; Kuncha, M.; Patra, C.R.; Reddy, P.N.C.; Banerjee, S.K. Hyperglycaemia enhances nitric oxide production in diabetes: A study from South Indian patients. PLoS ONE 2015, 10, e0125270. [CrossRef]

27. Yang, P.; Cao, Y.; Li, H. Hyperglycemia induces inducible nitric oxide synthase gene expression and consequent nitrosative stress via c-Jun N-terminal kinase activation. Am. J. Obstet. Gynecol. 2010, 203, e5-e185. [CrossRef]

28. Zhang, X.; Fu, Y.; Xu, X.; Li, M.; Du, L.; Han, Y.; Ge, Y. PERK pathway are involved in NO-induced apoptosis in endothelial cells cocultured with RPE under high glucose conditions. Nitric Oxide Biol. Chem. 2014, 40, 10-16. [CrossRef]

29. Assmann, T.S.; Brondani, L.A.; Bouças, A.P.; Rheinheimer, J.; de Souza, B.M.; Canani, L.H.; Bauer, A.C.; Crispim, D. Nitric oxide levels in patients with diabetes mellitus: A systematic review and meta-analysis. Nitric Oxide Biol. Chem. 2016, 61, 1-9. [CrossRef]

30. Bradley, S.A.; Steinert, J.R. Characterisation and comparison of temporal release profiles of nitric oxide generating donors. J. Neurosci. Meth. 2015, 245, 116-124. [CrossRef]

31. Bielarczyk, H.; Jankowska, A.; Madziar, B.; Matecki, A.; Michno, A.; Szutowicz, A. Differential toxicity of nitric oxide, aluminum, and amyloid beta-peptide in SN56 cholinergic cells from mouse septum. Neurochem. Int. 2003, 42, 323-331. [CrossRef]

32. Palmieri, E.M.; Gonzalez-Cotto, M.; Baseler, W.A.; Davies, L.C.; Ghesquière, B.; Maio, N.; Rice, C.M.; Rouault, T.A.; Cassel, T.; Higashi, R.M.; et al. Nitric oxide orchestrates metabolic rewiring in M1 macrophages by targeting aconitase 2 and pyruvate dehydrogenase. Nat. Commun. 2020, 11, 698. [CrossRef] [PubMed]

33. Feldman, E.L.; Callaghan, B.C.; Pop-Busui, R.; Zochodne, D.W.; Wright, D.E.; Bennett, D.L.; Bril, V.; Russell, J.W.; Viswanathan, V. Diabetic neuropathy. Nature Rev. Dis. Primers 2019, 5, 42. [CrossRef] [PubMed]

34. Benarroch, E.E. Brain glucose transporters: Implications for neurologic disease. Neurology 2014, 82, 1374-1379. [CrossRef] 
35. Zhao, L.; Dong, M.; Wang, D.; Ren, M.; Zheng, Y.; Zheng, H.; Li, C.; Gao, H. Characteristic metabolic alterations identified in primary neurons under high glucose exposure. Front. Cell Neurosci. 2018, 12, 207. [CrossRef]

36. Turner, D.A.; Adamson, D.C. Neuronal-astrocyte metabolic interactions: Understanding the transition into abnormal astrocytoma metabolism. J. Neuropath. Exp. Neur. 2011, 70, 167-176. [CrossRef]

37. Campbell, I.; Campbell, H. A pyruvate dehydrogenase complex disorder hypothesis for bipolar disorder. Med. Hypotheses 2019, 130, 109263. [CrossRef]

38. Yellen, G. Fueling thought: Management of glycolysis and oxidative phosphorylation in neuronal metabolism. J. Cell. Biol. 2018, 217, 2235-2246. [CrossRef]

39. Edmond, J.; Higa, T.A.; Korsak, R.A.; Bergner, E.A.; Lee, W.N.P. Fatty acid transport and utilization for the developing brain. J. Neurochem. 1998, 70, 1227-1234. [CrossRef]

40. Blázquez, C.; Sánchez, C.; Daza, A.; Galve-Roperh, I.; Guzmán, M. The stimulation of ketogenesis by cannabinoids in cultured astrocytes defines carnitine palmitoyltransferase I as a new ceramide-activated enzyme. J. Neurochem. 1999, 72, 1759-1768. [CrossRef]

41. Mahinpour, R.; Riazi, G.; Shokrgozar, M.A.; Sarbolouki, M.N.; Ahmadian, S.; Douraghi, M.; Alijanvand, H.H.; Azadmanesh, K.; Heidari, M.; Gheshlaghi, Z.N.; et al. Disruption of tubulin polymerization and cell proliferation by 1-naphthylarsonic acid. Cell Biol. Int. 2012, 36, 403-408. [CrossRef] [PubMed]

42. Wu, J.; Jin, Z.; Zheng, H.; Yan, L.J. Sources and implications of NADH/NAD+ redox imbalance in diabetes and its complications. Diabetes Metab. Syndr. Obes. 2016, 9, 145-153. [PubMed]

43. Jeong, J.Y.; Jeoung, N.H.; Park, K.G.; Lee, I.K. Transcriptional regulation of pyruvate dehydrogenase kinase. Diabetes Metab. J. 2016, 36, 328-335. [CrossRef] [PubMed]

44. Paidi, R.K.; Nthenge-Ngumbau, D.N.; Singh, R.; Kankanala, T.; Mehta, H.; Mehta, H.; Mohanakumar, K.P. Mitochondrial deficits accompany cognitive decline following single bilateral intracerebroventricular streptozotocin. Cur. Alzheimer Res. 2015, 12, 785-795. [CrossRef] [PubMed]

45. Wang, X.; Zheng, W.; Xie, J.W.; Wang, T.; Wang, S.L.; Teng, W.P.; Wang, Z.Y. Insulin deficiency exacerbates cerebral amyloidosis and behavioral deficits in an Alzheimer transgenic mouse model. Mol. Neurodegener. 2010, 5, 46. [CrossRef]

46. Pohanka, M. Alpha7 nicotinic acetylcholine receptor is a target in pharmacology and toxicology. Int. J. Mol. Sci. 2012, 13, 2219-2238. [CrossRef]

47. Brandon, E.P.; Mellott, T.; Pizzo, D.P.; Coufal, N.; D'Amour, K.A.; Gobeske, K.; Lortie, M.; López-Coviella, I.; Berse, B.; Thal, L.J.; et al. Choline transporter 1 maintains cholinergic function in choline acetyltransferase haploinsufficiency. J. Neurosci. 2004, 24, 5459-5466. [CrossRef]

48. Sherin, A.; Peeyush, K.T.; Jayanarayanan, S.; Amee, K.K.; Paulose, C.S. Decreased cholinergic receptor expression in the striatum: Motor function deficit in hypoglycemic and diabetic rats. Cell Mol. Neurobiol. 2012, 32, 83-93. [CrossRef]

49. Chandrasekharan, B.; Anitha, M.; Blatt, R.; Shahnavaz, N.; Kooby, D.; Staley, C.; Mwangi, S.; Jones, D.P.; Sitaraman, S.V.; Srinivasan, S. Colonic motor dysfunction in human diabetes is associated with enteric neuronal loss and increased oxidative stress. Neurogastroenterol. Motil. 2011, 23, e126-e131. [CrossRef]

50. Boison, D.; Chen, J.F.; Fredholm, B.B. Adenosine signaling and function in glial cells. Cell Death. Differ. 2010, 17, 1071-1082. [CrossRef]

51. Bathina, S.; Srinivas, N.; Das, U.N. Streptozotocin produces oxidative stress, inflammation and decreases BDNF concentrations to induce apoptosis of RIN5F cells and type 2 diabetes mellitus in Wistar rats. Biochem. Biophys. Res. Commun. 2017, 486, 406-413. [CrossRef] [PubMed]

52. Yang, H.; Fan, S.; Song, D.; Wang, Z.; Ma, S.; Li, S.; Li, X.; Xu, M.; Xu, M.; Wang, X. Long-term streptozotocin-induced diabetes in rats leads to severe damage of brain blood vessels and neurons via enhanced oxidative stress. Mol. Med. Rep. 2013, 7, 431-440. [CrossRef] [PubMed]

53. Zaroff, S.; Leone, P.; Markov, V.; Francis, J.S. Transcriptional regulation of N-acetylaspartate metabolism in the 5xFAD model of Alzheimer's disease: Evidence for neuron-glia communication during energetic crisis. Mol. Cell Neurosci. 2015, 65, 143-152. [CrossRef] [PubMed]

54. Tahay, G.; Wiame, E.; Tyteca, D.; Courtoy, P.J.; van Schaftingen, E. Determinants of the enzymatic activity and the subcellular localization of aspartate $\mathrm{N}$-acetyltransferase. Biochem. J. 2012, 441, 105-112. [CrossRef] [PubMed] 
55. Miyamoto, Y.; Ishikawa, Y.; Iegaki, N.; Sumi, K.; Fu, K.; Sato, K.; Furukawa-Hibi, Y.; Muramatsu, S.I.; Nabeshima, T.; Uno, K.; et al. Overexpression of Shati/Nat81, an N-acetyltransferase, in the nucleus accumbens attenuates the response to methamphetamine via activation of group II mGluRs in mice. Int. J. Neuropsychopharmacol. 2014, 17, 1283-1294. [CrossRef] [PubMed]

56. Sumi, K.; Uno, K.; Noike, H.; Tomohiro, T.; Hatanaka, Y.; Sumi, K.; Uno, K.; Noike, H.; Tomohiro, T.; Hatanaka, Y.; et al. Behavioral impairment in SHATI/NAT8L knockout mice via dysfunction of myelination development. Sci. Rep. 2017, 7, 16872. [CrossRef] [PubMed]

57. Jessen, F.; Lewczuk, P.; Gür, O.; Block, W.; Ende, G.; Frölich, L.; Hammen, T.; Arlt, S.; Kornhuber, J.; Kucinski, T.; et al. Association of $\mathrm{N}$-acetylaspartate and cerebrospinal fluid $\mathrm{A} \beta 42$ in dementia. J. Alzheimers Dis. 2011, 27, 393-399. [CrossRef] [PubMed]

58. Kantarci, K.; Jack, C.R. Neuroimaging in Alzheimer disease. an evidence-based review. Neuroimaging Clin. N. Am. 2003, 3, 197-209. [CrossRef]

59. Wang, H.; Tan, L.; Wang, H.F.; Liu, Y.; Yin, R.H.; Wang, W.Y.; Chang, X.L.; Jiang, T.; Yu, J.T. Magnetic Resonance Spectroscopy in Alzheimer's Disease: Systematic Review and Meta-Analysis. J. Alzheimers Dis. 2015, 46, 1049-1070. [CrossRef]

60. Watanabe, T.; Shiino, A.; Akiguchi, I. Hippocampal metabolites and memory performances in patients with amnestic mild cognitive impairment and Alzheimer's disease. Neurobiol. Learn. Mem. 2012, 97, 289-293. [CrossRef]

61. Ma, M.W.; Wang, J.; Zhang, Q.; Wang, R.; Dhandapani, K.M.; Vadlamudi, R.K.; Brann, D.W. NADPH oxidase in brain injury and neurodegenerative disorders. Mol. Neurodegener. 2017, 12, 7. [CrossRef]

62. Wang, X.; Lu, J.; Xie, W.; Lu, X.; Liang, Y.; Li, M.; Wang, Z.; Huang, X.; Tang, M.; Pfaff, D.W.; et al. Maternal diabetes induces autism-like behavior by hyperglycemia-mediated persistent oxidative stress and suppression of superoxide dismutase 2. Proc. Natl. Acad. Sci. USA. 2019, 116, 23743-23752. [CrossRef]

63. Kreft, E.; Kowalski, R.; Jankowski, M.; Szczepańska-Konkel, M. Renal vasculature reactivity to agonist of P2X7 receptor is increased in streptozotocin-induced diabetes. Pharmacol. Rep. 2016, 68, 71-74. [CrossRef]

64. Almandoz-Gil, L.; Persson, E.; Lindström, V.; Ingelsson, M.; Erlandsson, A.; Bergström, J. In situ proximity ligation assay reveals co-localization of alpha-synuclein and SNARE proteins in murine primary neurons. Front. Neurol. 2018, 9, 180. [CrossRef]

65. Slein, M.W.; Cori, G.T.; ori, C.F. A comparative study of hexokinase from yeast and animal tissues. J. Biol. Chem. 1950, 186, 763-780.

66. Koh, J.Y.; Choi, D.W. Quantitative determination of glutamate mediated cortical neuronal injury in cell culture by lactate dehydrogenase efflux assay. J. Neurosci. Methods 1987, 20, 83-90. [CrossRef]

67. Szutowicz, A.; Bielarczyk, H. Elimination of CoASH interference from acetyl-CoA cycling assay by maleic anhydride. Anal. Biochem. 1987, 164, 292-296. [CrossRef]

68. Contreras-Sanz, A.; Scott-Ward, T.S.; Gill, H.S.; Jacoby, J.C.; Birch, R.E.; Malone-Lee, J.; Taylor, K.M.G.; Peppiatt-Wildman, C.M.; Wildman, S.S.P. Simultaneous quantification of 12 different nucleotides and nucleosides released from renal epithelium and in human urine samples using ion-pair reversed-phase HPLC. Purinergic. Signal. 2012, 8, 741-751. [CrossRef]

69. Zhou, X.; He, P. Improved measurements of intracellular nitric oxide in intact microvessels using 4,5-diaminofluorescein diacetate. Am. J. Phys. Heart. Circ. Physiol. 2011, 301, H108-H114. [CrossRef]

70. Miranda, K.M.; Espey, M.G.; Wink, D.A. A rapid, simple spectrophotometric method for simultaneous detection of nitrate and nitrite. Nitric Oxide 2001, 5, 62-71. [CrossRef]

71. Gibon, Y.; Larher, F. Cycling assay for nicotinamide adenine dinucleotides: $\mathrm{NaCl}$ precipitation and ethanol solubilization of the reduced tetrazolium. Anal. Biochem. 1997, 251, 153-157. [CrossRef]

72. Zyśk, M.; Gapys, B.; Ronowska, A.; Gul-Hinc, S.; Erlandsson, A.; Iwanicki, A.; Sakowicz-Burkiewicz, M.; Szutowicz, A.; Bielarczyk, H. Protective effects of voltage-gated calcium channel antagonists against zinc toxicity in SN56 neuroblastoma cholinergic cells. PLOS ONE 2018, 13, e0209363.

Publisher's Note: MDPI stays neutral with regard to jurisdictional claims in published maps and institutional affiliations. 